Supporting Information

\title{
Synthesis of Platinum-Containing Conjugated Polymers Bearing Optically Active Amide Groups. Mechanistic Study of Chiral Aggregation
}

Taichi Sotani, Tatsuo Yajima, Hiromitsu Sogawa, and Fumio Sanda*

Department of Chemistry and Materials Engineering, Faculty of Chemistry, Materials and

Bioengineering, Kansai University, 3-3-35 Yamate-cho, Suita, Osaka 564-8680, Japan 


\section{CONTENTS}

Experimental Section S1-S10

Figures S1-S13. ${ }^{1} \mathrm{H}$ and ${ }^{13} \mathrm{C}$ NMR spectra of the monomers, precursors, model compounds and polymers. S11-S17

Figures S14-S16. IR spectra of the monomer and polymers. S18

Figures S17-S20. SEC traces of the monomers and polymers. S19-S20

Figures S21 and S22. UV-vis diffuse reflectance spectra of the monomers and polymers, and UVvis absorption spectra of the polymer.

Figures S23-S26. CD and UV-vis absorption spectra of the polymers and model compound, and DLS chart of the polymer.

Figure S27. POM images of the polymers. S25

Figures S28-S31 and Table S1. CD and UV-vis absorption spectra of the monomers and model compound of the polymer simulated by the TD-DFT method. S26-S30

Figures S32-S37. Relationships between thermodynamic energies of $\mathrm{Pt}(\mathrm{bpy})(\mathrm{C} \equiv \mathrm{C}-\mathrm{R})_{2}$ ••• $\mathrm{Pt}$ (bpy) $(\mathrm{C} \equiv \mathrm{C}-\mathrm{R})_{2}(\mathrm{R}=\mathrm{H}$ or $\mathrm{Ph})$ and the dihedral angle and $\mathrm{Pt}-\mathrm{Pt}$ distances between the dimer. S31-S34

Figure S38. Shape of HOMO-11 of a $\mathrm{Pt}(\mathrm{bpy})(\mathrm{C} \equiv \mathrm{C}-\mathrm{Ph})_{2} \bullet \bullet \mathrm{Pt}(\mathrm{bpy})(\mathrm{C} \equiv \mathrm{C}-\mathrm{Ph})_{2}$ association model. S35

Figure S39. CD and UV-vis absorption spectra of a $\mathrm{Pt}(\mathrm{bpy})(\mathrm{C} \equiv \mathrm{C}-\mathrm{Ph})_{2} \cdots \operatorname{Pt}(\mathrm{bpy})(\mathrm{C} \equiv \mathrm{C}-\mathrm{Ph})_{2}$ association model simulated by the TD-DFT method. S36

Figures S40-S43. CD and UV-vis absorption spectra of $\mathrm{Pt}(\mathrm{bpy})(\mathrm{C} \equiv \mathrm{C}-\mathrm{R})_{2} \bullet \bullet \operatorname{Pt}(\mathrm{bpy})(\mathrm{C} \equiv \mathrm{C}-\mathrm{R})_{2}(\mathrm{R}$ $=\mathrm{H}$ or $\mathrm{Ph}$ ) association model simulated by the TD-DFT method. S37-S40

Figure S44 and Table S2. Structures and geometry data of dimer association models. $\cdots$ S41-S42 Figures S45 and S46. Examination of stabilization upon association. S43-S44

References 


\section{EXPERIMENTAL SECTION}

Measurements. ${ }^{1} \mathrm{H}(400 \mathrm{MHz}),{ }^{13} \mathrm{C}(100 \mathrm{MHz})$ spectra were recorded on JEOL ECS-400 and JEOL ECZ-400 spectrometers. IR spectra were measured on a JASCO FT/IR-4100 spectrophotometer. Melting points (mp) were measured on a Yanaco micro melting point apparatus. Elemental analysis was performed at the analytical center, Faculty of Engineering, Osaka University. ESI-TOF mass spectra were measured on an Applied Biosystems APCI-3000 and a Shimadzu LCMS-IT-TOF. Single crystal X-ray analysis was performed using a Rigaku RAXIS RAPID-II system with graphite-monochromated MoK $\alpha$ radiation $(\lambda=0.71070 \AA)$. A crystal was mounted on a nylon loop at $-150{ }^{\circ} \mathrm{C}$. Three oscillation photographs were taken for each frame with an oscillation angle of $30^{\circ}$ and exposure for $30 \mathrm{~s}$ to determine the cell constant and orientation matrix. Intensity data were corrected from the oscillation photographs, and the reflection data were corrected for Lorentz and polarization effects. The structure was solved using the Olex 2 program. ${ }^{\mathrm{S} 1}$ Number-average molecular weight $\left(M_{\mathrm{n}}\right)$ and polydispersity $(\bigoplus)$ values of polymers were determined by size exclusion chromatography (SEC) on Shodex GPC KD-G×2, Shodex TSK-GEL $\alpha$ gel C0053×2, JASCO CO-965, JASCO UV-4570 Plus, JASCO RI-930, JASCO PU-4580 and JASCO DG-2080-53, using a solution of $\mathrm{LiBr}(10 \mathrm{mM})$ in DMF as an eluent at a flow rate of 1.0 $\mathrm{mL} / \mathrm{min}$, calibrated by polystyrene standards at $40^{\circ} \mathrm{C}$. UV-vis absorption spectra were recorded in a quartz cell (optical path length: $1 \mathrm{~cm}$ ) on a JASCO V-500 spectrometer. UV-vis diffuse reflectance spectra were recorded on a Shimadzu UV-2600 equipped with an integrating sphere ISR2500 plus. The samples of the diffuse reflectance spectra were diluted with $\mathrm{BaSO}_{4}$. Photoluminescence spectra were recorded in a quartz cell (optical path length: $1 \mathrm{~cm}$ ) on a JASCO FP-750. CD and UV-vis absorption spectra were recorded in a quartz cell (optical path length: 1 $\mathrm{cm}$ ) on a J-820 spectropolarimeter. Dynamic light scattering (DLS) measurements were performed using a square glass cell (PCS1115) on a Malvern Instruments Zetasizer Nano ZSP at $20{ }^{\circ} \mathrm{C}$. The 
measured autocorrelation function was analyzed using a cumulant method, and the $Z$-average values were calculated from the Stokes-Einstein equations. Polarizing microscopic (POM) observation was performed on a Nikon ECLIPSE LV100POL.

Materials. All solvents for the reaction and measurements were degassed by Ar bubbling and desiccated by molecular sieve 4A. All other reagents were commercially obtained and used as received without purification. Dichloro(4,4'-di-tert-butyl-2,2'-bipyridine)platinum (1a), dichloro(4,4'-dinonyl-2,2'-bipyridine)platinum (1b), methyl-3,5-dibromobenzoate, L-alanine dodecylamide, 1-iodo-4-[2-(trimethylsilyl)ethynyl]benzene and 1-ethynyl-4-[2(trimethylsilyl)ethynyl]benzene were synthesized according to the literature. ${ }^{\text {S2-S5 }}$

Synthesis of Monomer and Model Compound. Monomer 2 and model compound M1 were synthesized according to Schemes S1 and S2. The procedures were as follows.

\section{Methyl 3,5-bis[2-(trimethylsilyl)ethynyl]benzoate (3)}

Methyl 3,5-dibromobenzoate (7.35 g, $25.0 \mathrm{mmol}), \mathrm{PdCl}_{2}\left(\mathrm{PPh}_{3}\right)_{2}$ (175 mg, $\left.0.25 \mathrm{mmol}\right)$, $\mathrm{CuI}$ (48 mg, $0.25 \mathrm{mmol})$ and $\mathrm{PPh}_{3}(66 \mathrm{mg}, 0.25 \mathrm{mmol})$ were dissolved in pyridine $(60 \mathrm{~mL})$ and $\mathrm{Et}_{3} \mathrm{~N}(20 \mathrm{~mL})$ under Ar. Trimethylsilylacetylene $(9.9 \mathrm{~mL}, 70.0 \mathrm{mmol}$ ) was added to the solution, and the resulting mixture was stirred at $80{ }^{\circ} \mathrm{C}$ overnight. It was filtered and concentrated on a rotary evaporator to obtain a solid mass. $\mathrm{Et}_{2} \mathrm{O}(200 \mathrm{~mL})$ was added to the mass, and the organic layer was washed with water and $1.0 \mathrm{M} \mathrm{NH} 4 \mathrm{Cl}$ aq, dried over anhydrous $\mathrm{MgSO}_{4}$, and concentrated using a rotary evaporator. The residual mass was purified by silica gel column chromatography eluted with hexane-hexane $/ \mathrm{CH}_{2} \mathrm{Cl}_{2}=2 / 1(\mathrm{v} / \mathrm{v})$ gradient to obtain 3 as a yellow solid $(6.72 \mathrm{~g}, 20.4 \mathrm{mmol})$. Yield $=82 \% .{ }^{1} \mathrm{H} \mathrm{NMR}\left(400 \mathrm{MHz}, \mathrm{CDCl}_{3}\right): \delta 0.25\left(\mathrm{~s}, 18 \mathrm{H},-\mathrm{Si}\left(\mathrm{CH}_{3}\right)_{3}\right), 3.91\left(\mathrm{~s}, 3 \mathrm{H}, \mathrm{COOCH}_{3}\right), 7.72(\mathrm{Ar}$, 
1H), 8.04 (Ar, 2H). ${ }^{13} \mathrm{C}$ NMR (100 MHz, $\left.\mathrm{CDCl}_{3}\right):-0.2,96.1,102.9(-\mathrm{C} \equiv \mathrm{C}-), 123.9,130.5,132.6$, 139.0 (Ar), $165.6(>\mathrm{C}=\mathrm{O})$.

\section{3,5-Diethynylbenzoic Acid (4)}

Compound 3 (4.98 g, $17.0 \mathrm{mmol})$ and $\mathrm{KOH}$ (5.72 g, $102.0 \mathrm{mmol})$ were dissolved in $\mathrm{MeOH}$ (100 $\mathrm{mL}$ ), and the resulting solution was stirred at $40{ }^{\circ} \mathrm{C}$ for $5 \mathrm{~h}$. After that, $1.0 \mathrm{M} \mathrm{HCl}$ aq was added dropwise to the resulting mixture until the $\mathrm{pH}$ became 1.0. It was extracted with $\mathrm{CHCl}_{3}(100 \mathrm{~mL} \times$ 3), and the combined organic layer was dried over anhydrous $\mathrm{MgSO}_{4}$, then concentrated using a rotary evaporator to obtain 4 as a yellow solid $(2.35 \mathrm{~g}, 13.8 \mathrm{mmol})$. Yield $=81 \%$. ${ }^{1} \mathrm{H}$ NMR $(400$ $\left.\mathrm{MHz}, \mathrm{CDCl}_{3}\right): \delta 3.16(\mathrm{~s}, 2 \mathrm{H}, \mathrm{C} \equiv \mathrm{C}-\mathrm{H}), 7.81(1 \mathrm{H}, \mathrm{Ar}), 8.15-8.27$ (2H, Ar).

\section{N-(3,5-Diethynylbenzoyl)-L-alanine Dodecylamide (5)}

$N$-Methylmorpholine $(3.5 \mathrm{~mL}, 32.0 \mathrm{mmol})$ and isobutyl chloroformate $(4.2 \mathrm{~mL}, 32.0 \mathrm{mmol})$ were subsequently added to a solution of $4(5.41 \mathrm{~g}, 31.8 \mathrm{mmol})$ in DMF $(60 \mathrm{~mL})$ at $0{ }^{\circ} \mathrm{C}$. After stirring for $30 \mathrm{~min}$, a solution of $\mathrm{L}$-alanine dodecylamide $(8.15 \mathrm{~g}, 31.8 \mathrm{mmol})$ in $\mathrm{CHCl}_{3}(100 \mathrm{~mL})$ and $\mathrm{DMF}$ (40 mL) was added to the resulting mixture, which was stirred overnight and concentrated. $\mathrm{CHCl}_{3}$ (200 $\mathrm{mL}$ ) was added to the residual mass, and the resulting solution was washed with water, dried over anhydrous $\mathrm{MgSO}_{4}$, and concentrated. The residual mass was purified by recrystallization with hexane/ethyl acetate to obtain 5 as a white solid $(7.53 \mathrm{~g}, 18.4 \mathrm{mmol})$. Yield $=58 \%$. ${ }^{1} \mathrm{H}$ NMR (400 $\left.\mathrm{MHz}, \mathrm{CDCl}_{3}\right): \delta 0.88\left(\mathrm{t}, 3 \mathrm{H}, J=6.4 \mathrm{~Hz},-\mathrm{CH}_{3}\right), 1.17-1.36\left(\mathrm{~m}, 18 \mathrm{H},-\left(\mathrm{CH}_{2}\right)_{9}-\right), 1.41-1.59(\mathrm{~m}, 3 \mathrm{H}$, $\left.-\mathrm{CH}\left(\mathrm{CH}_{3}\right)-\right), 3.14(\mathrm{~s}, 2 \mathrm{H}, \mathrm{C} \equiv \mathrm{C}-\mathrm{H}), 3.20-3.33\left(\mathrm{~m}, 2 \mathrm{H},-\mathrm{NHCH}_{2}-\right), 4.60-4.71(\mathrm{~m}, 1 \mathrm{H},-\mathrm{CH}<), 6.26$ (br, 1H, -NH-), 7.02 (br, 1H, -NH-), 7.71 (s, 1H, Ar), 7.87 (d, 2H, J=1.4 Hz, Ar). ${ }^{13} \mathrm{C}-\mathrm{NMR}(100$ $\left.\mathrm{MHz}, \mathrm{CDCl}_{3}\right): \delta 14.1\left(-\mathrm{CH}_{2} \mathrm{CH}_{2} \mathrm{CH}_{3}\right), 18.9\left(-\mathrm{CH}_{3}\right), 22.6\left(-\mathrm{CH}_{2} \mathrm{CH}_{2} \mathrm{CH}_{3}\right), 26.9\left(-\mathrm{CH}_{2} \mathrm{CH}_{2} \mathrm{CH}_{3}\right)$, 
29.2, 29.3, 29.4, 29.5, 29.6, 29.6, $31.9\left(-\left(\mathrm{CH}_{2}\right)_{7}-\right), 39.7\left(-\mathrm{NHCH}_{2}-\right), 49.4(-\mathrm{CH}-), 79.0(-\mathrm{C} \equiv \mathrm{C}-)$, $81.6(-\mathrm{C} \equiv \mathrm{C}-), 123.1,130.9,134.5,138.2(\mathrm{Ar}), 165.3(\mathrm{C}=\mathrm{O}), 172.0(>\mathrm{C}=\mathrm{O})$.

\section{1-Iodo-4-[2-(trimethylsilyl)ethynyl]benzene (6)}

4-Iodoaniline (6.57 g, $30.0 \mathrm{mmol}), \mathrm{PdCl}_{2}\left(\mathrm{PPh}_{3}\right)_{2}(210 \mathrm{mg}, 0.30 \mathrm{mmol}), \mathrm{CuI}(57.1 \mathrm{mg}, 0.30 \mathrm{mmol})$ and $\mathrm{PPh}_{3}(78.7 \mathrm{mg}, 0.30 \mathrm{mmol})$ were dissolved in THF $(20 \mathrm{~mL})$ and $\mathrm{Et}_{3} \mathrm{~N}(20 \mathrm{~mL})$ under Ar. Trimethylsilylacetylene $(4.4 \mathrm{~mL}, 31.0 \mathrm{mmol})$ was added to the resulting mixture. It was stirred at r.t. overnight, and the mixture was filtered and concentrated. Ethyl acetate $(150 \mathrm{~mL})$ was added to the residue, and the solution was subsequently washed with water and $1.0 \mathrm{M} \mathrm{NH}_{4} \mathrm{Cl}$ aq. The organic layer was dried over anhydrous $\mathrm{MgSO}_{4}$, concentrated, and the residual mass was purified by silica gel column chromatography eluted with hexane/ $\mathrm{CH}_{2} \mathrm{Cl}_{2}=1 / 1 \quad(\mathrm{v} / \mathrm{v})$ to obtain 4-[2(trimethylsilyl)ethynyl]aniline as a yellow solid $(5.11 \mathrm{~g}, 27.0 \mathrm{mmol})$. Yield $=90 \%$. A solution of $\mathrm{NaNO}_{2}(2.07 \mathrm{~g}, 30.0 \mathrm{mmol})$ in water $(10 \mathrm{~mL})$ was added to a solution of 4-[2(trimethylsilyl)ethynyl]aniline $(5.11 \mathrm{~g}, 27.0 \mathrm{mmol})$ in concentrated hydrochloric acid $(100 \mathrm{~mL})$ dropwise at $0{ }^{\circ} \mathrm{C}$. The resulting mixture was stirred at $0{ }^{\circ} \mathrm{C}$ for $1 \mathrm{~h}$, and then an ice-cooled solution of KI (11.9 g, $72.0 \mathrm{mmol})$ in water $(10 \mathrm{~mL})$ was added to the mixture dropwise. The resulting mixture was stirred at $0{ }^{\circ} \mathrm{C}$ for $1 \mathrm{~h}$, and then at r.t. overnight. The resulting mixture was extracted with $\mathrm{CH}_{2} \mathrm{Cl}_{2}(100 \mathrm{~mL} \times 3)$, and the combined organic layer was concentrated. Hexane $(200 \mathrm{~mL})$ was added to the residue, and the resulting precipitate was removed by filtration. The filtrate was concentrated, and the residual mass was purified by silica gel column chromatography eluted with hexane to obtain 6 as a white solid $(6.48 \mathrm{~g}, 21.6 \mathrm{mmol})$. Yield $=80 \% .{ }^{1} \mathrm{H}$ NMR $\left(400 \mathrm{MHz}, \mathrm{CDCl}_{3}\right)$ : $\delta 0.22$ (s, 9H), 7.15-7.24 (Ar, 2H), 7.59-7.77 (Ar, 2H). $\left.{ }^{13} \mathrm{C} \mathrm{NMR} \mathrm{(100} \mathrm{MHz,} \mathrm{CDCl}_{3}\right): \delta-0.01,94.6$ $(-\mathrm{C} \equiv \mathrm{C}-), 96.0(-\mathrm{C} \equiv \mathrm{C}-), 122.7,133.5,137.5(\mathrm{Ar})$. 


\section{N-[3,5-Bis(4-(trimethylsilylethynyl)phenylethynyl)benzoyl]-L-alanine Dodecylamide (7)}

Compound 5 (1.26 g, $3.09 \mathrm{mmol}), 6$ (1.83 g, $6.10 \mathrm{mmol}), \mathrm{PdCl}_{2}\left(\mathrm{PPh}_{3}\right)_{2}(21.0 \mathrm{mg}, 0.03 \mathrm{mmol}), \mathrm{CuI}$ (5.7 $\mathrm{mg}, 0.03 \mathrm{mmol})$ and $\mathrm{PPh}_{3}(7.9 \mathrm{mg}, 0.30 \mathrm{mmol})$ were dissolved in pyridine $(10 \mathrm{~mL})$ and $\mathrm{Et}_{3} \mathrm{~N}$ $(20 \mathrm{~mL})$ under Ar. The resulting solution was stirred at $50{ }^{\circ} \mathrm{C}$ overnight. The mixture was filtered, concentrated, and dissolved in $\mathrm{Et}_{2} \mathrm{O}(200 \mathrm{~mL})$. The resulting solution was washed with water and 1.0 $\mathrm{M} \mathrm{NH}_{4} \mathrm{Cl}$ aq, dried over anhydrous $\mathrm{MgSO}_{4}$, concentrated, and the residual mass was purified by silica gel column chromatography eluted with $\mathrm{CHCl}_{3} /$ ethyl acetate $=20 / 1(\mathrm{v} / \mathrm{v})$ to obtain 7 as a white-yellow solid $(1.78 \mathrm{~g}, 2.36 \mathrm{mmol})$. Yield $=79 \% .{ }^{1} \mathrm{H}$ NMR $\left(400 \mathrm{MHz}, \mathrm{CDCl}_{3}\right): \delta 0.26(\mathrm{~s}, 18 \mathrm{H}$, $\left.-\mathrm{Si}\left(\mathrm{CH}_{3}\right)_{3}\right), 0.87\left(\mathrm{t}, J=6.4 \mathrm{~Hz}, 3 \mathrm{H},-\mathrm{CH}_{3}\right), 1.05-1.37\left(\mathrm{~m}, 18 \mathrm{H},-\left(\mathrm{CH}_{2}\right)_{9}-\right), 1.37-1.62(\mathrm{~m}, 3 \mathrm{H},-$ $\left.\mathrm{CH}\left(\mathrm{CH}_{3}\right)-\right), 3.10-3.34\left(\mathrm{~m}, 2 \mathrm{H},-\mathrm{NHCH}_{2}-\right), 4.57-4.80$ (m, 1H, $\left.-\mathrm{CH}<\right), 6.63$ (br, $\left.1 \mathrm{H},-\mathrm{NH}-\right), 7.12-$ 7.29 (br, 1H, -NH-), 7.32-7.52 (m, 8H, Ar), 7.68-7.76 (m, 1H, Ar), 7.81-7.92 (m, 1H, Ar). ${ }^{13} \mathrm{C}$ NMR (100 MHz, $\left.\mathrm{CDCl}_{3}\right): \delta-0.12\left(-\mathrm{Si}\left(\mathrm{CH}_{3}\right)_{3}\right), 14.1,18.9,22.7,26.9,29.2,29.3$ 29.4, 29.5, 29.5, 29.6, 31.9, 39.7, 49.4, 89.3 (-C $\equiv \mathrm{C}-), 90.7(-\mathrm{C} \equiv \mathrm{C}-), 96.6(-\mathrm{C} \equiv \mathrm{C}-), 104.4(-\mathrm{C} \equiv \mathrm{C}-), 122.5,123.4$, $124.1,129.8,131.5,131.9,137.0(\mathrm{Ar}), 165.5,172.0(>\mathrm{C}=\mathrm{O})$.

\section{N-[3,5-Bis(4-ethynylphenylethynyl)benzoyl]-L-alanine Dodecylamide (2)}

A solution of $\mathrm{NaOH}(0.31 \mathrm{~g}, 7.72 \mathrm{mmol})$ in $\mathrm{MeOH}(20 \mathrm{~mL})$ was added to a solution of $7(1.69 \mathrm{~g}$, $2.24 \mathrm{mmol}$ ). The resulting solution was stirred at r.t. for $30 \mathrm{~min}$ to precipitate a white mass. It was dissolved in $\mathrm{CH}_{2} \mathrm{Cl}_{2}(100 \mathrm{~mL} \times 3)$, and the solution was washed with water, dried over $\mathrm{MgSO}_{4}$, and concentrated. The residual mass was purified by eluting with $\mathrm{CHCl}_{3} /$ ethyl acetate $=20 / 1(\mathrm{v} / \mathrm{v})$ to obtain 3 as a white-yellow solid $(1.20 \mathrm{~g}, 1.97 \mathrm{mmol})$. Yield $=88 \% . \mathrm{Mp}=166-167{ }^{\circ} \mathrm{C} .{ }^{1} \mathrm{H}$ NMR (400 MHz, $\left.\mathrm{CDCl}_{3}\right): \delta 0.87\left(\mathrm{t}, J=6.4 \mathrm{~Hz}, 3 \mathrm{H},-\mathrm{CH}_{3}\right), 1.05-1.37(\mathrm{~m}, 18 \mathrm{H}), 1.37-1.62(\mathrm{~m}, 3 \mathrm{H},-$ $\left.\mathrm{CH}\left(\mathrm{CH}_{3}\right)-\right), 3.19(\mathrm{~s}, 2 \mathrm{H},-\mathrm{C} \equiv \mathrm{C}-\mathrm{H}), 3.25-3.34\left(\mathrm{~m}, 2 \mathrm{H},-\mathrm{NHCH}_{2}-\right), 4.64-4.73(\mathrm{~m}, 1 \mathrm{H},-\mathrm{CH}<), 6.23$ (br, 1H, -NH-), 7.07 (br, 1H, -NH-), 7.45-7.52 (m, 8H, Ar), 7.75-7.81 (m, 1H, Ar), 7.87-7.93 (m, 
2H, Ar). ${ }^{1} \mathrm{H}$ NMR (400 MHz, DMF- $\left.d_{7}\right): \delta 0.87\left(\mathrm{~m}, 3 \mathrm{H},-\mathrm{CH}_{3}\right), 1.20-1.36\left(\mathrm{~m}, 18 \mathrm{H},-\left(\mathrm{CH}_{2}\right)_{9}-\right)$, $1.42-1.56\left(\mathrm{~m}, 3 \mathrm{H},-\mathrm{CH}\left(\mathrm{CH}_{3}\right)-\right), 3.14-3.31\left(\mathrm{~m}, 2 \mathrm{H},-\mathrm{NHCH}_{2}-\right), 4.31-4.47(\mathrm{~s}, 2 \mathrm{H},-\mathrm{C} \equiv \mathrm{C}-\mathrm{H}), 4.54-$ $4.74(\mathrm{~m}, 1 \mathrm{H},-\mathrm{CH}<), 7.54-7.81(\mathrm{Ar}, 8 \mathrm{H}), 7.90-7.99$ (Ar, 1H), 8.17-8.32 (Ar, 2H). ${ }^{13} \mathrm{C}$ NMR (100 $\left.\mathrm{MHz}, \mathrm{CDCl}_{3}\right): \delta-0.12\left(-\mathrm{Si}\left(\mathrm{CH}_{3}\right)_{3}\right), 14.1,18.9,22.7,26.9,29.2,29.3$ 29.4, 29.5, 29.5, 29.6, 31.9, 39.7, 49.4, $79.2(-\mathrm{C} \equiv \mathrm{C}-), 83.1(-\mathrm{C} \equiv \mathrm{C}-), 89.4(-\mathrm{C} \equiv \mathrm{C}-), 90.5(-\mathrm{C} \equiv \mathrm{C}-), 122.4,122.9,124.0,129.9$, 131.5, 132.1, 134.5, $137.0(\mathrm{Ar}), 165.5,172.0(\mathrm{C}=\mathrm{O})$. ESI-TOF-MS: $m / z$ calcd for $[\mathrm{M}+\mathrm{H}]^{+}$: 609.3481: found 609.3492. Elem. Anal. Calcd for $\mathrm{C}_{42} \mathrm{H}_{44} \mathrm{~N}_{2} \mathrm{O}_{2}$ : C, 82.86; H, 7.28; N, 4.60; found: C, 82.32; H, 7.01; N, 4.21.

\section{Bis[2-(4-(2-trimethylsily)ethynylphenyl)ethynyl]-(4,4'-di-tert-butyl-2,2'-bipyridine)platinum} (M2)

Dichloro(4,4'-di-tert-butyl-2,2'-bipyridine)platinum (1a) (265.2 mg, 0.50 mmol), 1-ethynyl-4-[2(trimethylsilyl)ethynyl]benzene (218.2 mg, $1.10 \mathrm{mmol})$, CuI (10 mg, $0.05 \mathrm{mmol})$ were dissolved in $i \operatorname{Pr}_{2} \mathrm{NH}(10 \mathrm{~mL})$ under Ar. The resulting solution was stirred at $50{ }^{\circ} \mathrm{C}$ overnight. The mixture was concentrated and dissolved in $\mathrm{CH}_{2} \mathrm{Cl}_{2}(50 \mathrm{~mL})$. The resulting solution was washed with water and $1.0 \mathrm{M} \mathrm{NH} 4 \mathrm{Cl}$ aq, dried over anhydrous $\mathrm{MgSO}_{4}$, concentrated, and the residual mass was purified by silica gel column chromatography eluted with $\mathrm{CHCl}_{3}$ to obtain $\mathbf{M} 2$ as a yellow solid $(425 \mathrm{mg}, 0.50 \mathrm{mmol})$. Yield $=$ quant. ${ }^{1} \mathrm{H} \mathrm{NMR}\left(400 \mathrm{MHz}, \mathrm{CDCl}_{2} \mathrm{CDCl}_{2}\right): \delta 0.23\left(\mathrm{~s}, 18 \mathrm{H},-\mathrm{Si}\left(\mathrm{CH}_{3}\right)_{3}\right)$, $1.48\left(\mathrm{~s}, 18 \mathrm{H},-\mathrm{C}\left(\mathrm{CH}_{3}\right)_{3}\right), 7.39(\mathrm{Ar}, 8 \mathrm{H}), 7.59(\mathrm{Ar}, 2 \mathrm{H}), 7.91(\mathrm{Ar}, 2 \mathrm{H}), 9.54(\mathrm{Ar}, 2 \mathrm{H}) .{ }^{13} \mathrm{C} \mathrm{NMR}(100$ $\left.\mathrm{MHz}, \mathrm{CD}_{2} \mathrm{Cl}_{2} \mathrm{CD}_{2} \mathrm{Cl}_{2}\right): \delta 0.0,30.1,35.6,77.3,90.8,95.1,118.8,119.6,128.2,131.5,131.6,150.7$, $155.9,163.7$.

Bis[2-(4-ethynylphenyl)ethynyl]-(4,4'-di-tert-butyl-2,2'-bipyridine)platinum (M1) 
A solution of M2 (385 mg, $0.45 \mathrm{mmol})$ in THF $(22.6 \mathrm{~mL})$ was added to a solution of KOH (126 $\mathrm{mg}, 2.25 \mathrm{mmol})$ in $\mathrm{MeOH}(11.3 \mathrm{~mL})$. The resulting solution was stirred for $30 \mathrm{~min}$ at r.t., concentrated, and dissolved in $\mathrm{CH}_{2} \mathrm{Cl}_{2}(100 \mathrm{~mL})$. It was washed with water, dried over anhydrous $\mathrm{MgSO}_{4}$, concentrated to obtain a yellow solid as M1 (297 mg, $\left.0.42 \mathrm{mmol}\right)$. Yield: 93\%. A single crystal of $\mathbf{M 1}$ was prepared by slow diffusing hexane into a solution of $\mathbf{M 1}$ in $\mathrm{CHCl}_{2} \mathrm{CHCl}_{2} .{ }^{1} \mathrm{H}$ NMR (400 MHz, $\left.\mathrm{CDCl}_{2} \mathrm{CDCl}_{2}\right): \delta 1.41\left(\mathrm{~s}, 18 \mathrm{H},-\mathrm{C}\left(\mathrm{CH}_{3}\right)_{3}\right), 3.17(-\mathrm{C} \equiv \mathrm{C}-\mathrm{H}), 7.42(\mathrm{Ar}, 8 \mathrm{H}), 7.58$ (Ar, 2H), $\left.7.92(\mathrm{Ar}, 2 \mathrm{H}), 9.54(\mathrm{Ar}, 2 \mathrm{H}) .{ }^{13} \mathrm{C} \mathrm{NMR} \mathrm{(100} \mathrm{MHz,} \mathrm{CD}_{2} \mathrm{Cl}_{2} \mathrm{CD}_{2} \mathrm{Cl}_{2}\right): \delta 30.3,35.9,78.4$, 84.4, 91.2, 118.7, 119.1, 125.0, 129.0, 132.0, 151.0, 156.2, 164.1. ESI-TOF-MS: $m / z$ calcd for $[\mathrm{M}$ $+\mathrm{H}]^{+}:$714.2448: found 714.2406. 


\section{Scheme S1. Synthetic Route for Monomer 2}
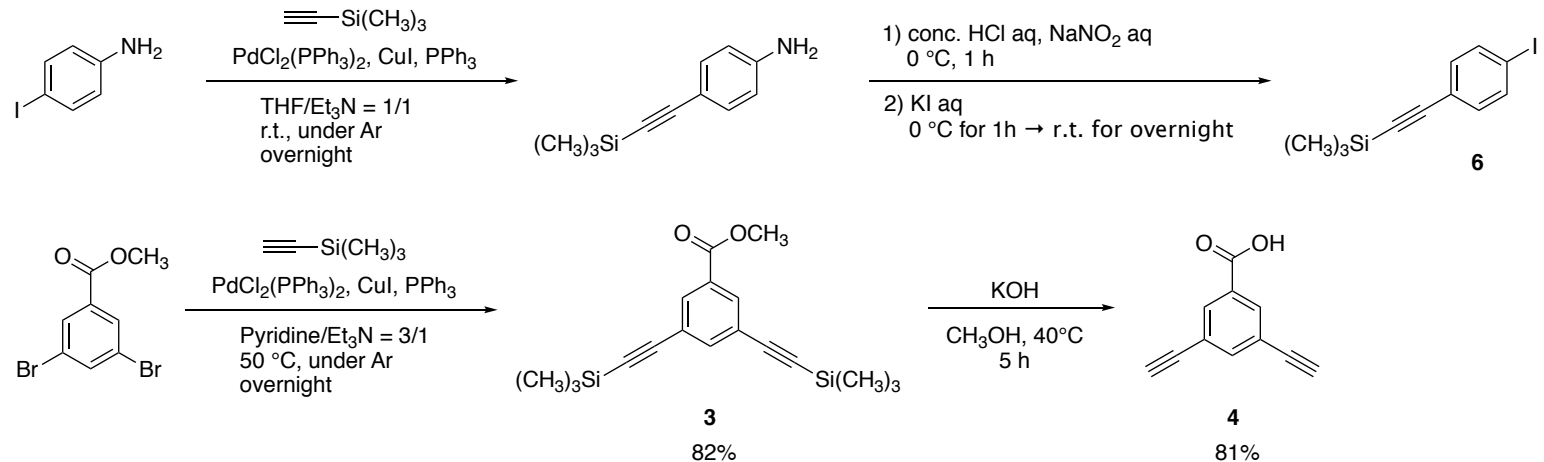

$82 \%$

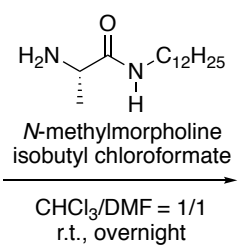
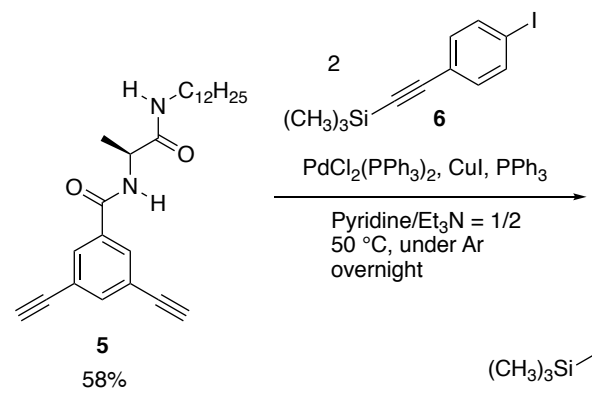

overnight

$58 \%$
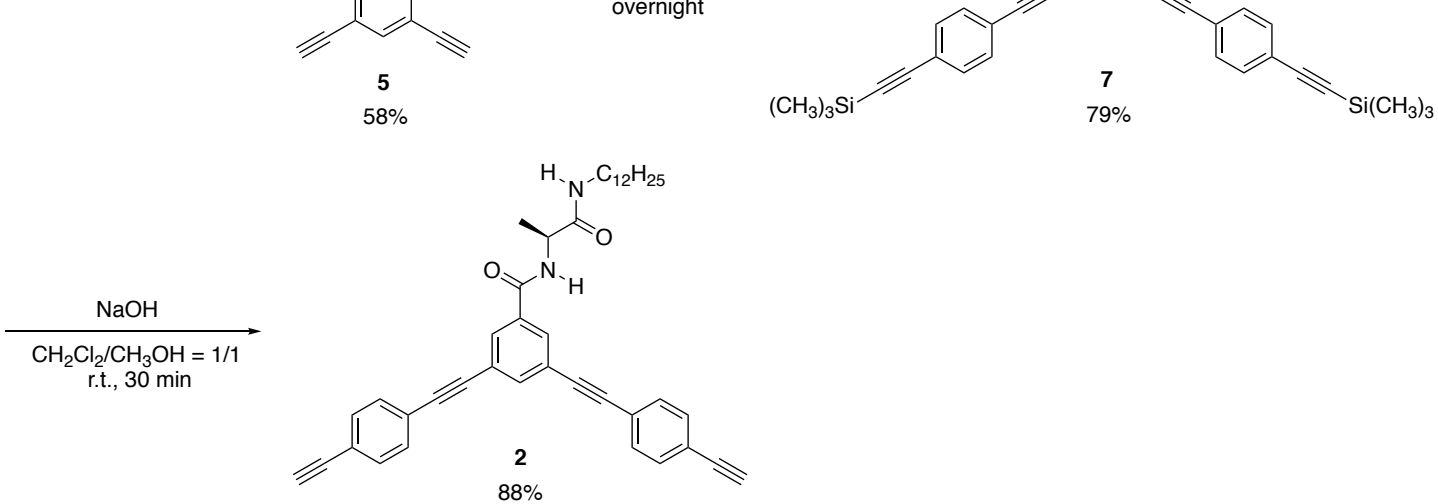

\section{Scheme S2. Synthetic Route for Model Compound M1}

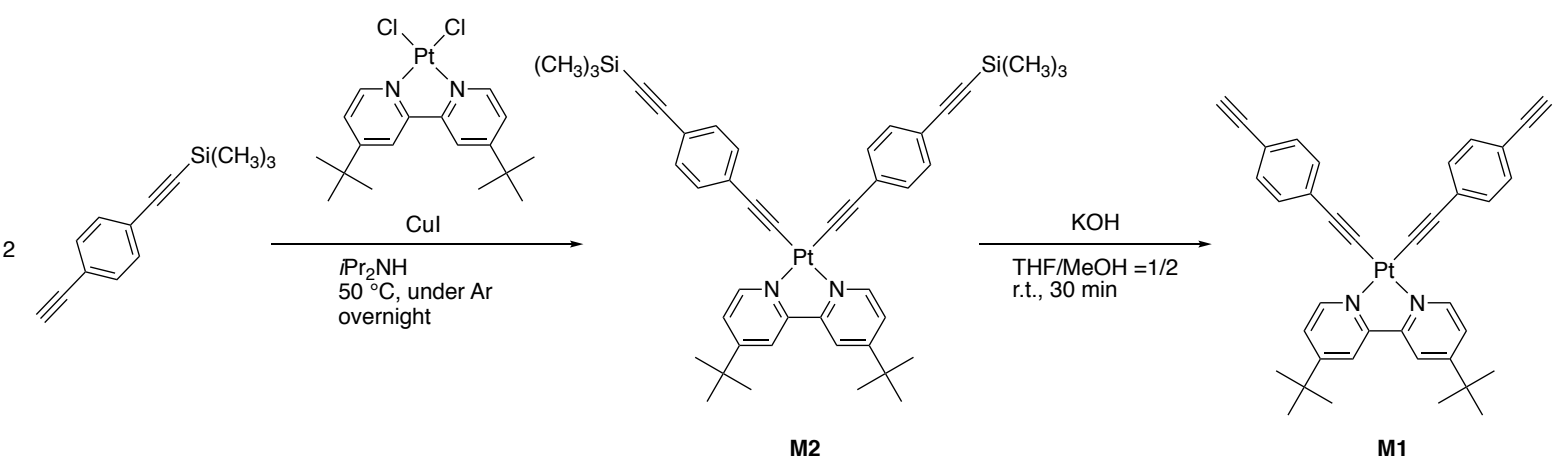


Synthesis of Polymers. All polymerizations were carried out in a Schlenk tube under Ar. Typical procedure: A solution of $\mathrm{CuI}(1.9 \mathrm{mg})$ in $i \mathrm{Pr}_{2} \mathrm{NH}(0.1 \mathrm{~mL})$ were added to a solution of $\mathbf{1 a}(53.4 \mathrm{mg}$, $0.10 \mathrm{mmol})$ and $2(60.9 \mathrm{mg}, 0.10 \mathrm{mmol})$ in $\mathrm{CH}_{2} \mathrm{Cl}_{2}(5.0 \mathrm{~mL})$ and $i \mathrm{Pr}_{2} \mathrm{NH}(4.9 \mathrm{~mL})$ under Ar, and the resulting solution was stirred at $25^{\circ} \mathrm{C}$ for $18 \mathrm{~h}$. Then, the reaction mixture was concentrated and dissolved in a small amount of DMF $(10 \mathrm{~mL})$. The solution was poured into a large amount of $\mathrm{MeOH}$ to precipitate a solid. It was separated by filtration using a membrane filter (ADVANTEC H100A047A), washed with large amount of $\mathrm{MeOH}$, and dried in vacuo to obtain poly(1a-2) (102 $\mathrm{mg}, 0.095 \mathrm{mmol})$ Yield = quant. Poly $(\mathbf{1 b}-\mathbf{2})$ was synthesized in a manner similar to the synthesis of poly(1a-2). Poly(1b-2) obtained by the polymerization in $\mathrm{CH}_{2} \mathrm{Cl}_{2} / i \mathrm{Pr}_{2} \mathrm{NH}=1 / 1(\mathrm{v} / \mathrm{v})$ was insoluble in common organic solvents including $\mathrm{CHCl}_{3}, \mathrm{CH}_{2} \mathrm{Cl}_{2}$, DMF and THF. In this case, the solvent-insoluble solid was immersed in a large amount of DMF, separated by filtration, and subsequently washed with $\mathrm{DMF}$ and $\mathrm{MeOH}$, and dried in vacuo to obtain purified poly(1)-2).

Spectroscopic Data of the Polymers. Poly(1a-2): IR (KBr): 3315, 3070, 2920, 2851, 2205, 2105, $1645,1616,1581,1501,1464,1426,1363,1220,1172,1098,959,886,834,761,742,722,679$, 646, 627, 611, 594, 543, $512 \mathrm{~cm}^{-1} .{ }^{1} \mathrm{H}$ NMR (400 MHz, DMF- $\left.d_{7}\right): \delta 0.81-0.91$ (br, $3 \mathrm{H},-\mathrm{CH}_{3}$ ), 1.20-1.32 (br, 18H, - $\left.\left(\mathrm{CH}_{2}\right)_{9}-\right)$, 1.45-1.54 (br, 21H, $\left.-\mathrm{C}\left(\mathrm{CH}_{3}\right)_{3},-\mathrm{CH}\left(\mathrm{CH}_{3}\right)-\right), 3.14-3.23$ (br, 2H, $\mathrm{NHCH}_{2}-$ ), 4.51-4.70 (br, 1H, $-\mathrm{CH}<$ ), 8.01-8.06 (Ar, 9H), 8.10-8.24 (br, Ar, 2H), 8.77-8.87 (br, Ar, 2H), 9.54-9.71 (br, Ar, 2H). Poly(1b-2): IR (KBr): 3315, 3070, 2920, 2851, 2205, 2105, 1644, $1616,1581,1501,1464,1426,1363,1220,1172,1098,959,886,834,761,742,722,679,646$,

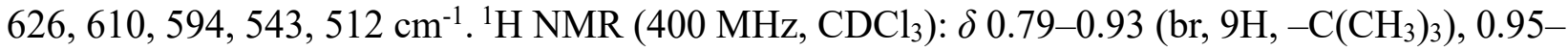
$1.66\left(\mathrm{br}, 55 \mathrm{H},-\left(\mathrm{CH}_{2}\right)_{9-},-\left(\mathrm{CH}_{2}\right)_{8}-\times 2,-\mathrm{CH}\left(\mathrm{CH}_{3}\right)<, 3.20-3.38\left(\mathrm{br}, 2 \mathrm{H},-\mathrm{NHCH}_{2}-\right), 4.51-4.95\right.$ (br, $1 \mathrm{H},-\mathrm{CH}<), 6.07-6.24$ (br, 1H, $-\mathrm{NH}<$ ), 6.94-7.04 (br, 1H, -NH<), 7.25-8.05 (m, 15H, Ar), 9.34$9.56(\mathrm{br}, 2 \mathrm{H}, \mathrm{Ar})$. 
Computations. All computational calculations were performed with the Gaussian 16 program, ${ }^{\mathrm{S} 6}$ ES64L-G16 Rev B.01, running on the supercomputer systems, Academic Center for Computing and Media Studies, Kyoto University, and Institute for Chemical Research, Kyoto University. The energies were calculated by the DFT method ${ }^{\mathrm{S} 7}$ with the M06 and $\omega \mathrm{B} 97 \mathrm{XD}$ functionals in conjunction with the basis sets, $6-31 \mathrm{G}^{*}, 6-311 \mathrm{G}^{*}, 6-311+\mathrm{G}^{*}$ for $\mathrm{C}, \mathrm{H}, \mathrm{N}$, and LANL2DZ, SDD for $\mathrm{Pt}$ in a vacuum environment. The initial geometries of $\mathrm{Pt}(\mathrm{bpy})(\mathrm{C} \equiv \mathrm{C}-\mathrm{R})_{2} \cdots \operatorname{Pt}(\mathrm{bpy})(\mathrm{C} \equiv \mathrm{C}-\mathrm{R})_{2}$ association models $(\mathrm{R}=\mathrm{H}$ and $\mathrm{Ph})$ were constructed based on the geometries of single crystals $\mathrm{X}$ ray data of M1 [Figure 8, (b)]. Two $\operatorname{Pt}(\mathrm{bpy})(\mathrm{C} \equiv \mathrm{C}-\mathrm{H})_{2}$ molecules were aligned parallel to each other with Pt-Pt distance at $3.8 \AA$. The $\mathrm{CD}$ and UV-vis absorption spectra of $\mathrm{Pt}(\mathrm{bpy})(\mathrm{C} \equiv \mathrm{C}-\mathrm{R})_{2} \cdots$ $\mathrm{Pt}(\mathrm{bpy})(\mathrm{C} \equiv \mathrm{C}-\mathrm{R})_{2}$ association models $(\mathrm{R}=\mathrm{H}$ and $\mathrm{Ph})$ were simulated by the TD-DFT method using the same series of basis sets as described above. The low-energy transition states $(n=20-120)$ were predicted to calculate the oscillator strength and rotatory strength $\left(R_{\mathrm{vel}}\right)$ in the velocity form. The simulated CD and UV-vis absorption spectra were plotted based on these values with peak halfwidth at half height $=0.2 \mathrm{eV}$ using GaussView 6. The Boltzmann weight distributions of the $\mathrm{Pt}(\mathrm{bpy})(\mathrm{C} \equiv \mathrm{C}-\mathrm{R})_{2} \cdots \operatorname{Pt}(\mathrm{bpy})(\mathrm{C} \equiv \mathrm{C}-\mathrm{R})_{2}(\mathrm{R}=\mathrm{H}$ or $\mathrm{Ph})$ association models with various dihedral angles $\left[\Phi=0^{\circ}-360^{\circ}\right.$, Figure 10, (c) and (g)], and Figure S33, (c)] were calculated from Boltzmann probability of association models, which were calculated by the following equation:

$$
\text { [Boltzmann probability] }=10 \frac{-\Delta G^{\circ}}{2.303 R T}
$$

where $\Delta G^{\circ}, R$, and $T$ are the Gibbs free energy of $\operatorname{Pt}(\mathrm{bpy})(\mathrm{C} \equiv \mathrm{C}-\mathrm{R})_{2} \cdots \operatorname{Pt}(\mathrm{bpy})(\mathrm{C} \equiv \mathrm{C}-\mathrm{R})_{2}$ association models, gas constant, and absolute temperature (298 K), respectively. 


\section{NMR Spectra}

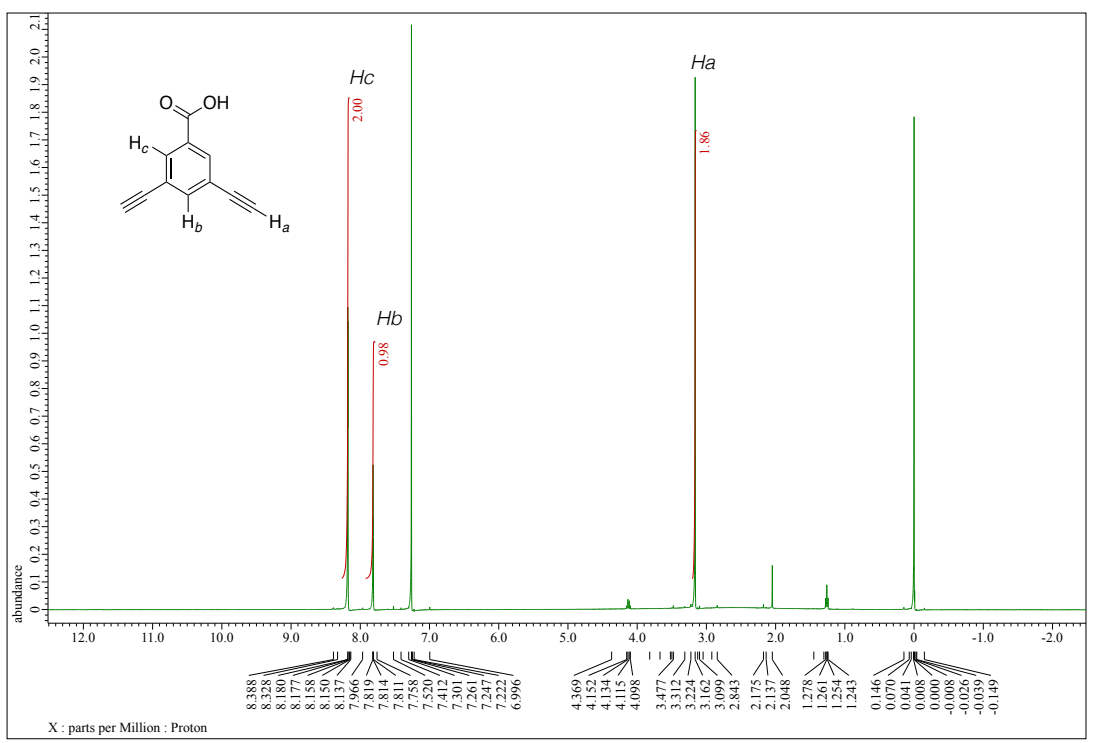

Figure S1. ${ }^{1} \mathrm{H}$ NMR spectrum $\left(400 \mathrm{MHz}, \mathrm{CDCl}_{3}\right)$ of 4.

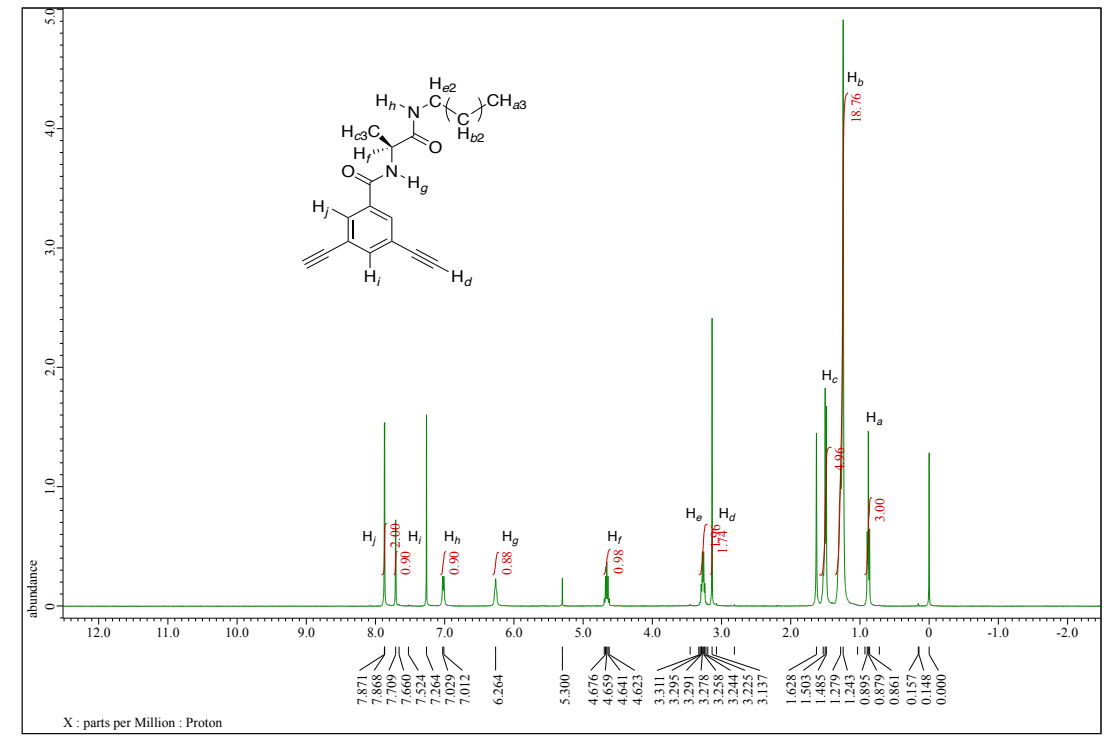

Figure S2. ${ }^{1} \mathrm{H}$ NMR spectrum $\left(400 \mathrm{MHz}, \mathrm{CDCl}_{3}\right)$ of 5. 


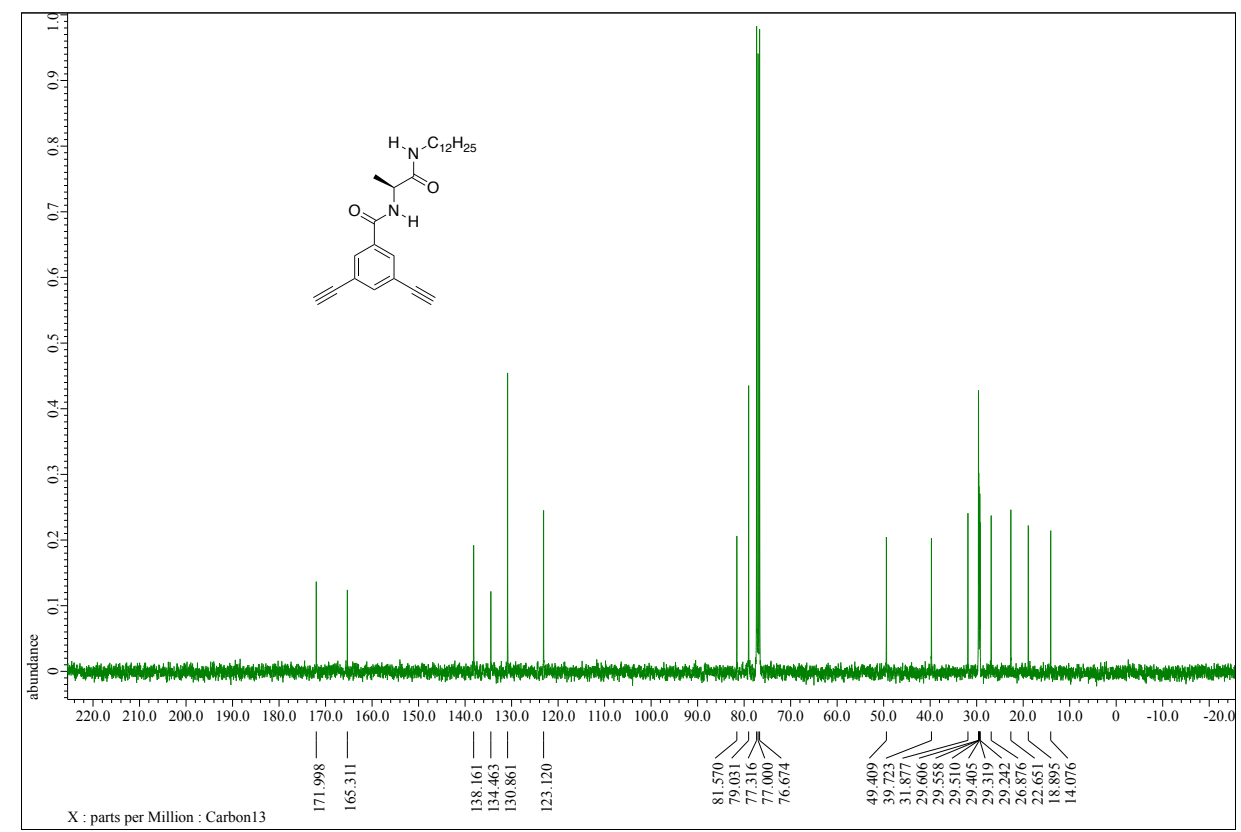

Figure S3. ${ }^{13} \mathrm{C}$ NMR spectrum $\left(100 \mathrm{MHz}, \mathrm{CDCl}_{3}\right)$ of 5.

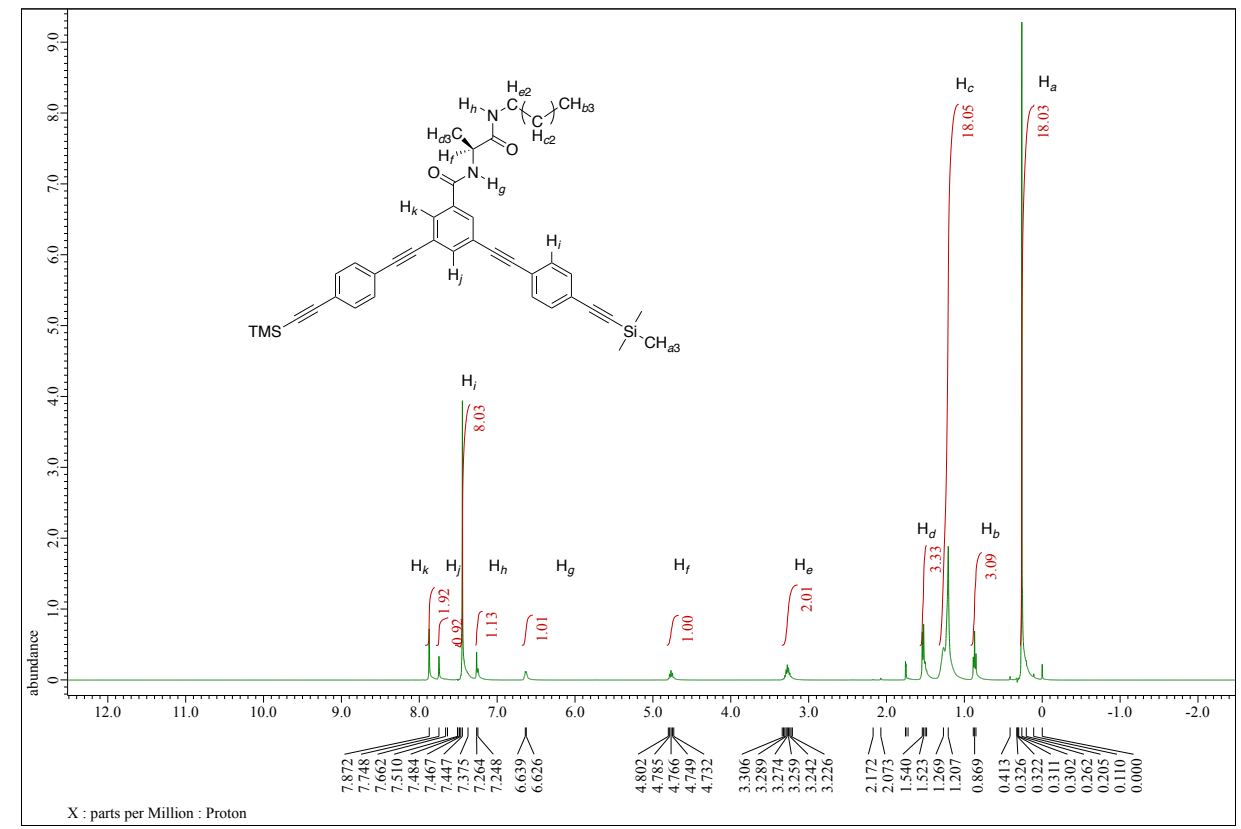

Figure S4. ${ }^{1} \mathrm{H} \mathrm{NMR}$ spectrum $\left(400 \mathrm{MHz}, \mathrm{CDCl}_{3}\right)$ of 6 . 


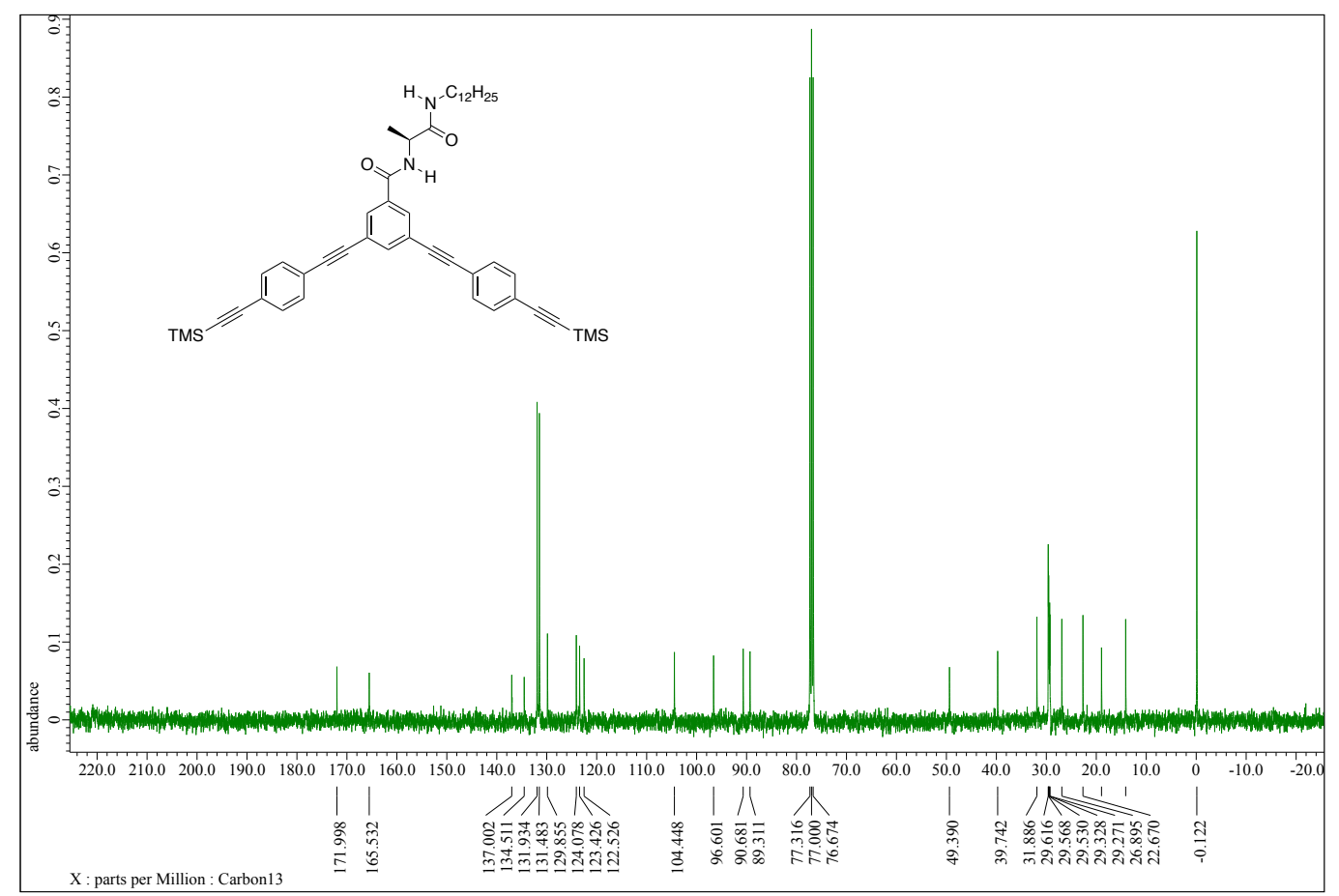

Figure S5. ${ }^{13} \mathrm{C}$ NMR spectrum $\left(100 \mathrm{MHz}, \mathrm{CDCl}_{3}\right)$ of 6.

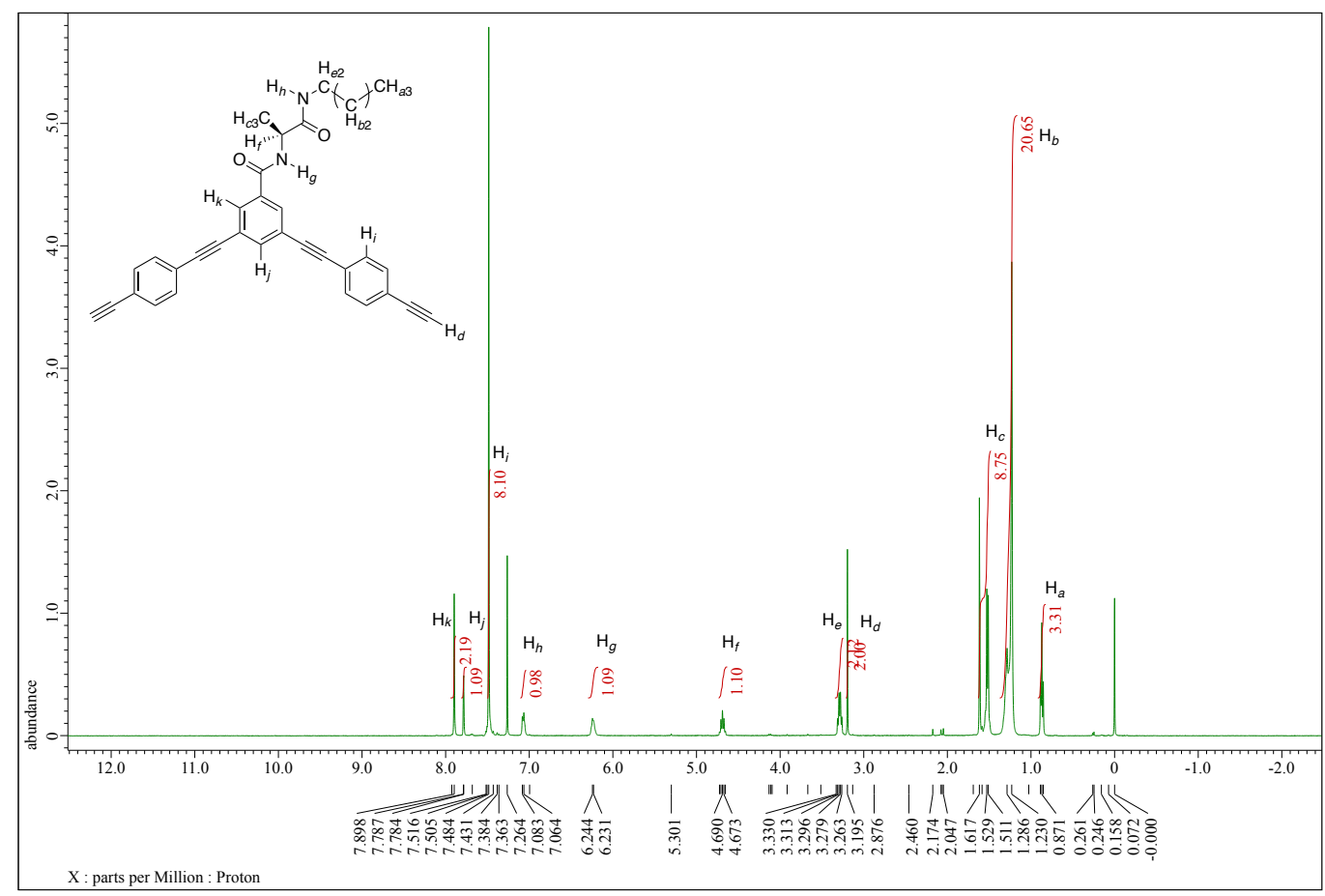

Figure S6. ${ }^{1} \mathrm{H}$ NMR spectrum $\left(400 \mathrm{MHz}, \mathrm{CDCl}_{3}\right)$ of 2. 


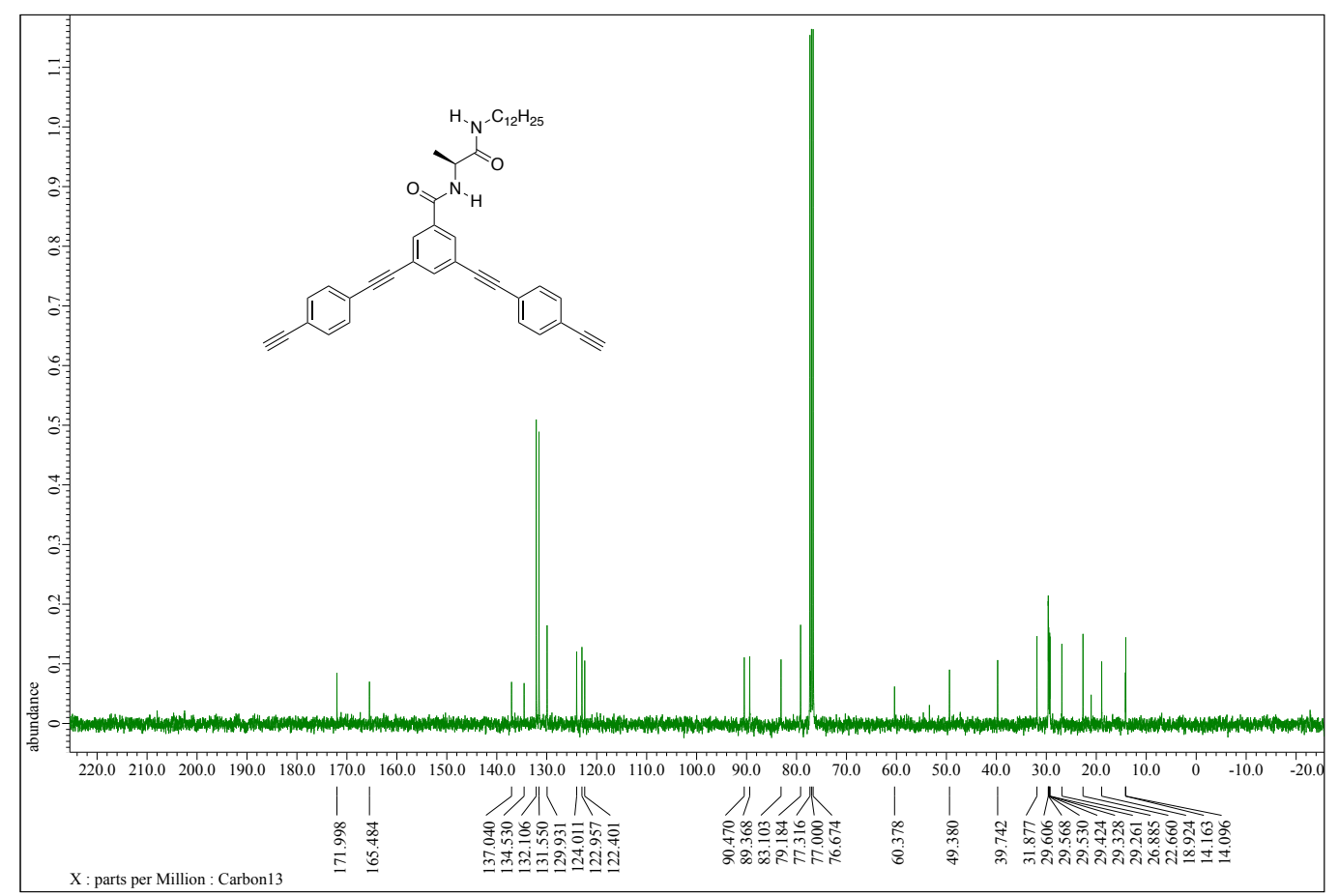

Figure S7. ${ }^{13} \mathrm{C}$ NMR spectrum $\left(100 \mathrm{MHz}, \mathrm{CDCl}_{3}\right)$ of 2.

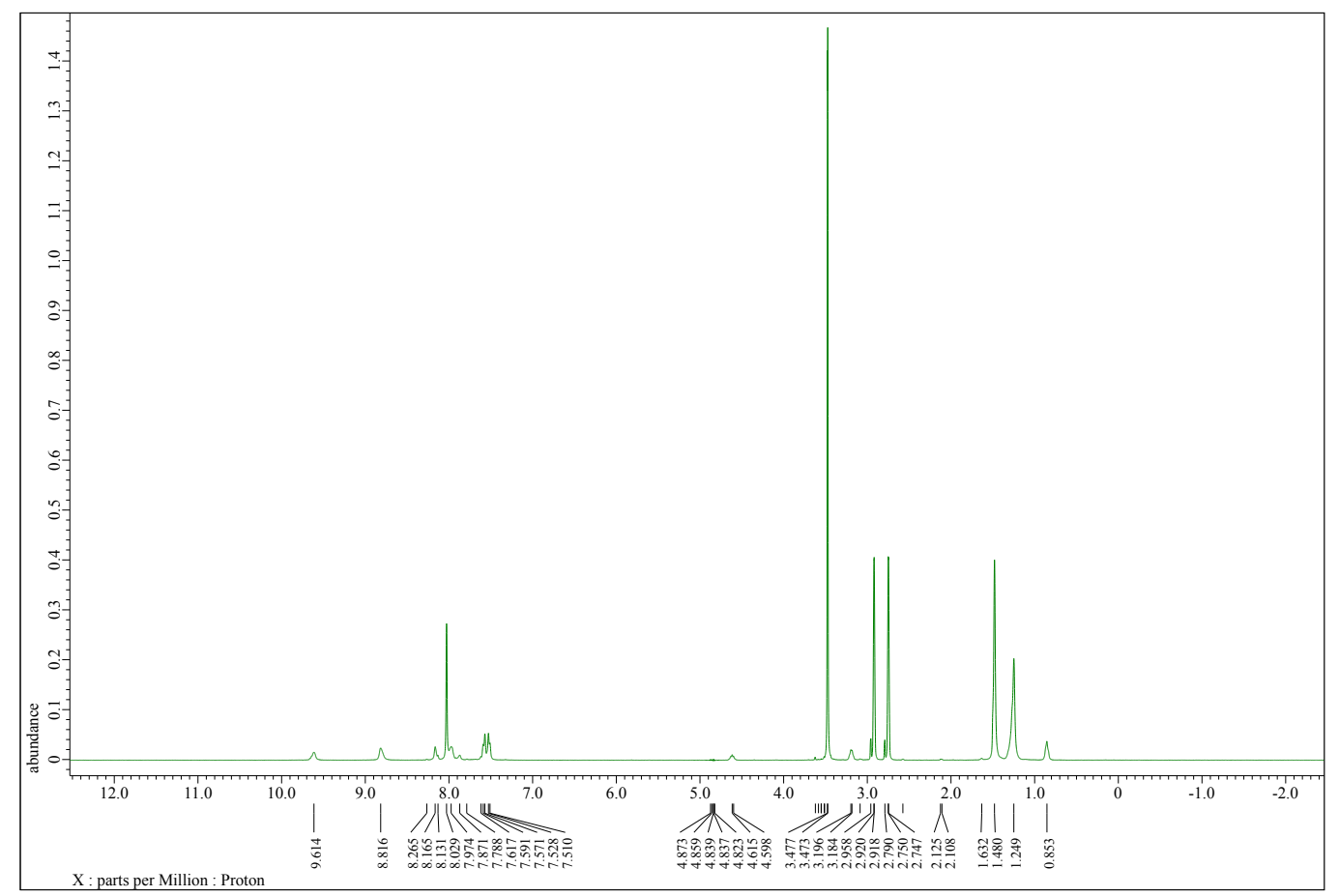

Figure S8. ${ }^{1} \mathrm{H}-\mathrm{NMR}$ spectrum $\left(400 \mathrm{MHz}, \mathrm{DMF}-d_{7}\right)$ of poly(1a-2). 


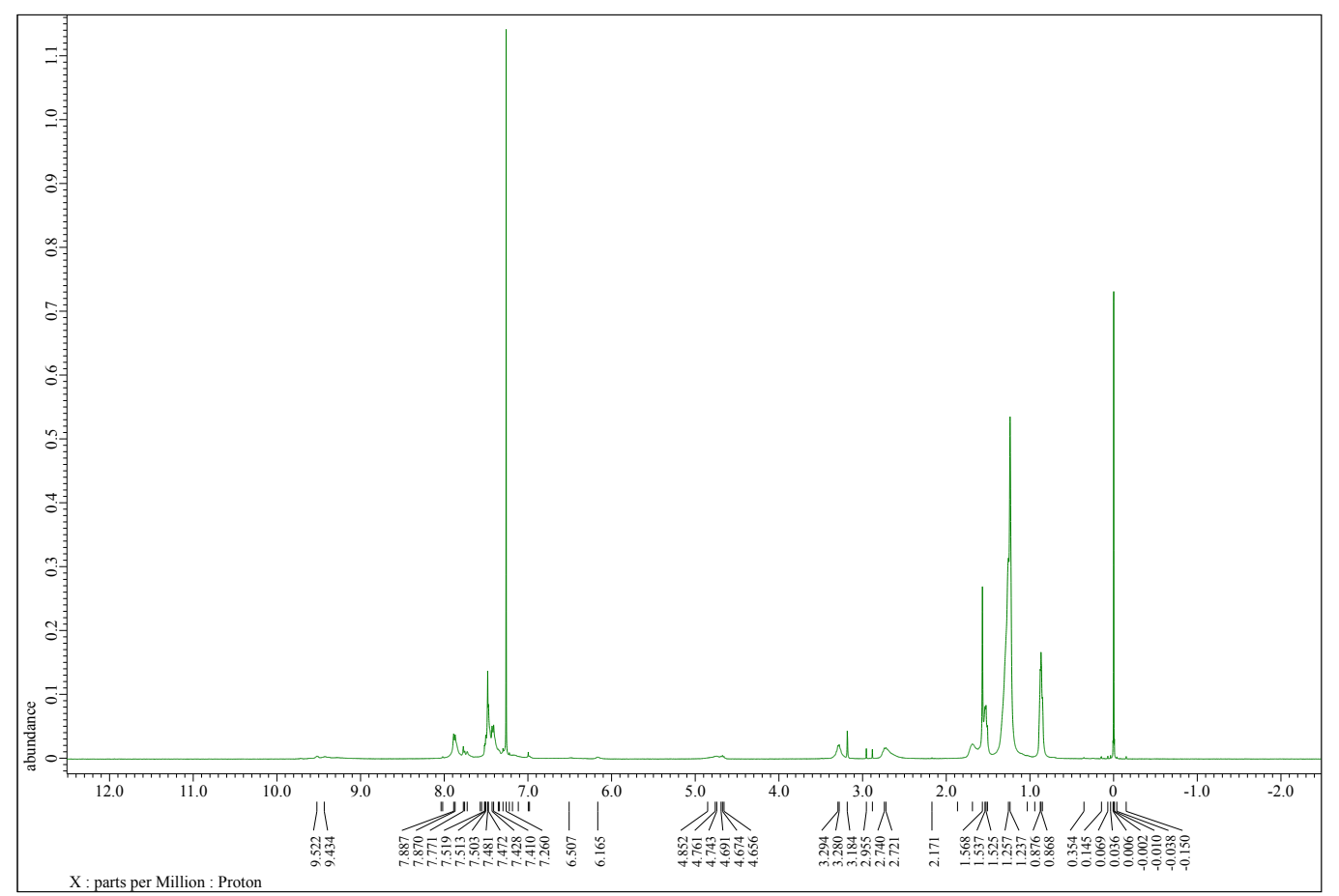

Figure S9. ${ }^{1} \mathrm{H}-\mathrm{NMR}$ spectrum $\left(400 \mathrm{MHz}, \mathrm{CDCl}_{3}\right)$ of soluble parts of poly(1b-2).

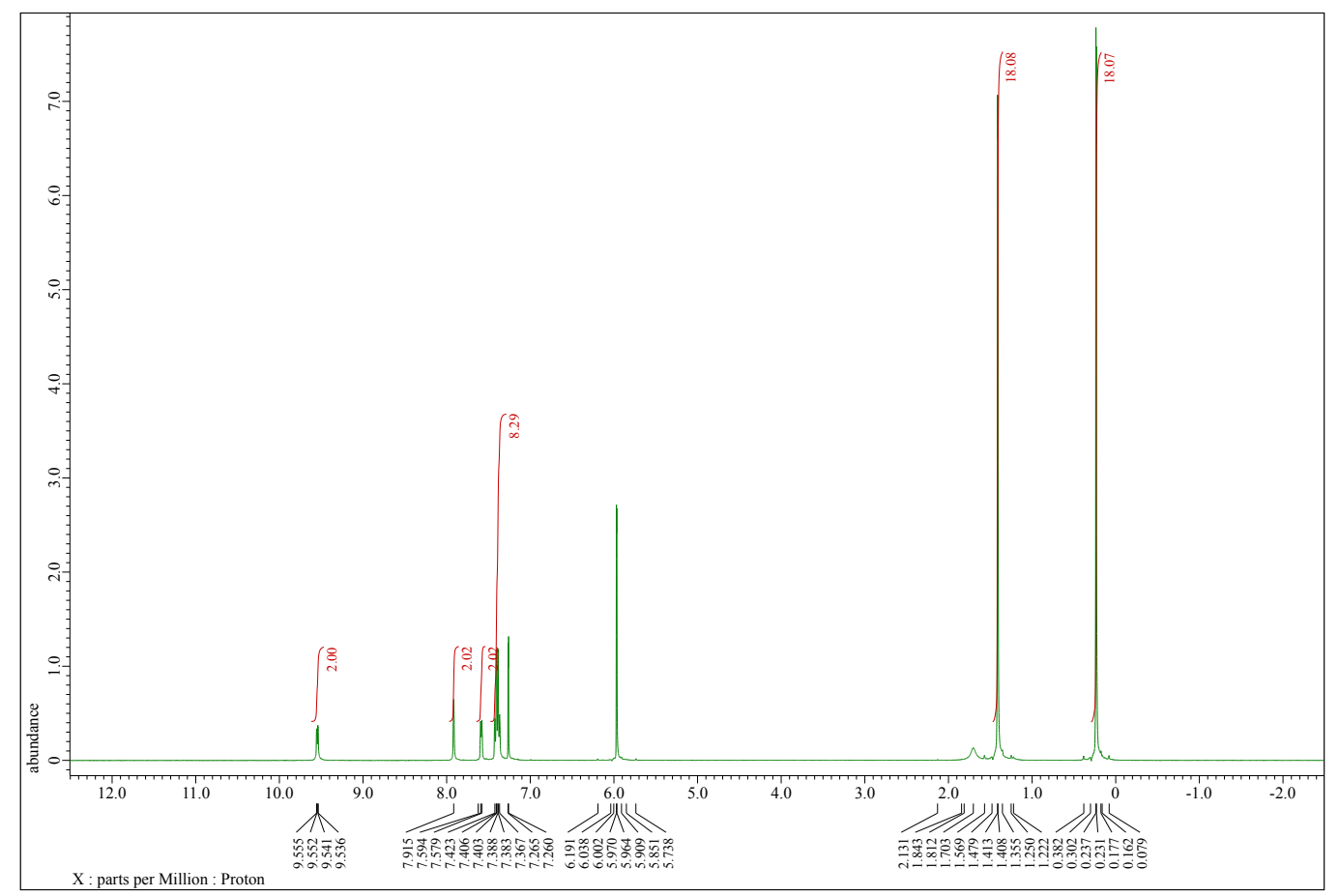

Figure S10. ${ }^{1} \mathrm{H}$ NMR spectrum $\left(400 \mathrm{MHz}, \mathrm{CDCl}_{2} \mathrm{CDCl}_{2}\right)$ of $\mathbf{M} 2$. 


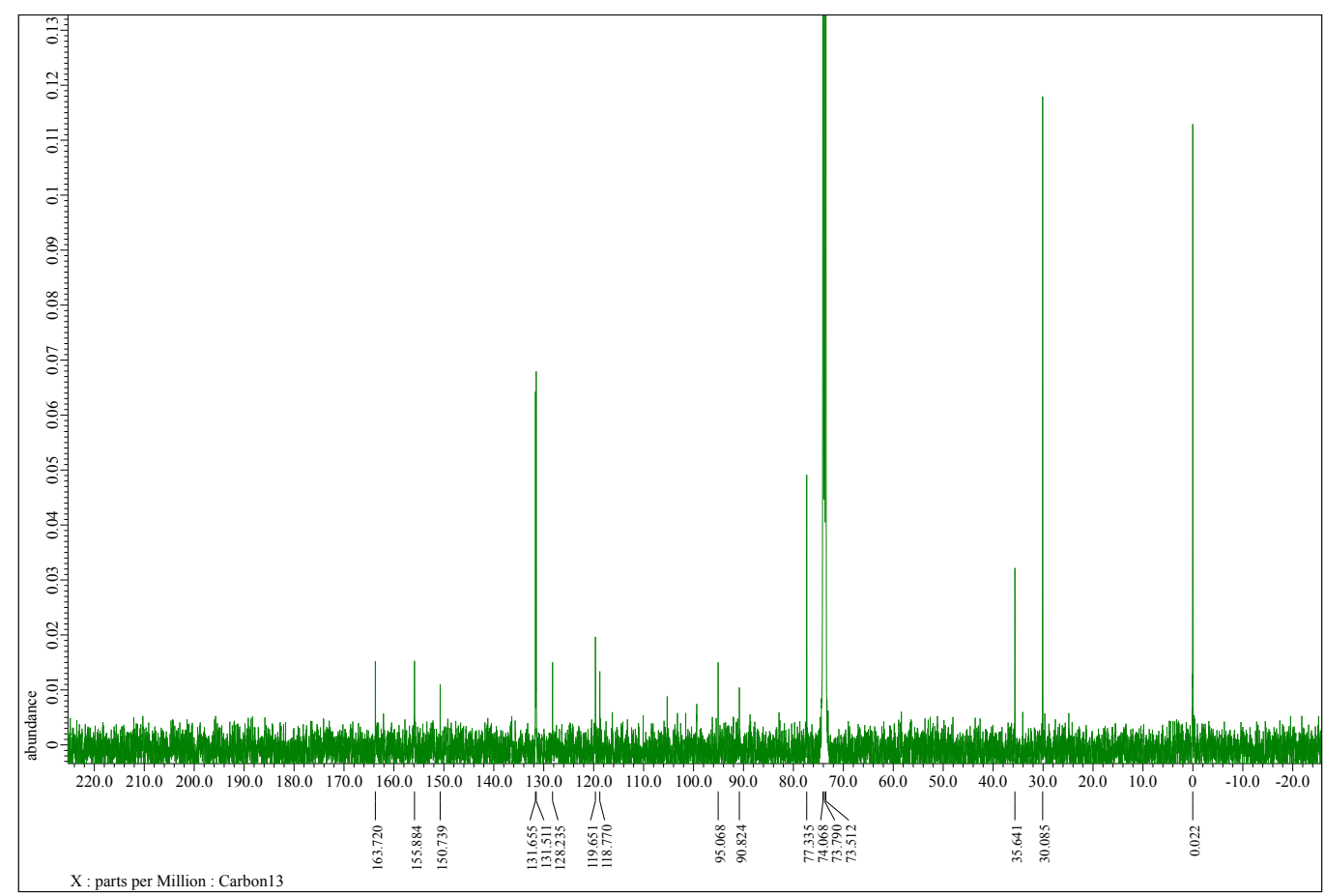

Figure S11. ${ }^{13} \mathrm{C}$ NMR spectrum $\left(100 \mathrm{MHz}, \mathrm{CDCl}_{2} \mathrm{CDCl}_{2}\right)$ of $\mathbf{M 2}$.

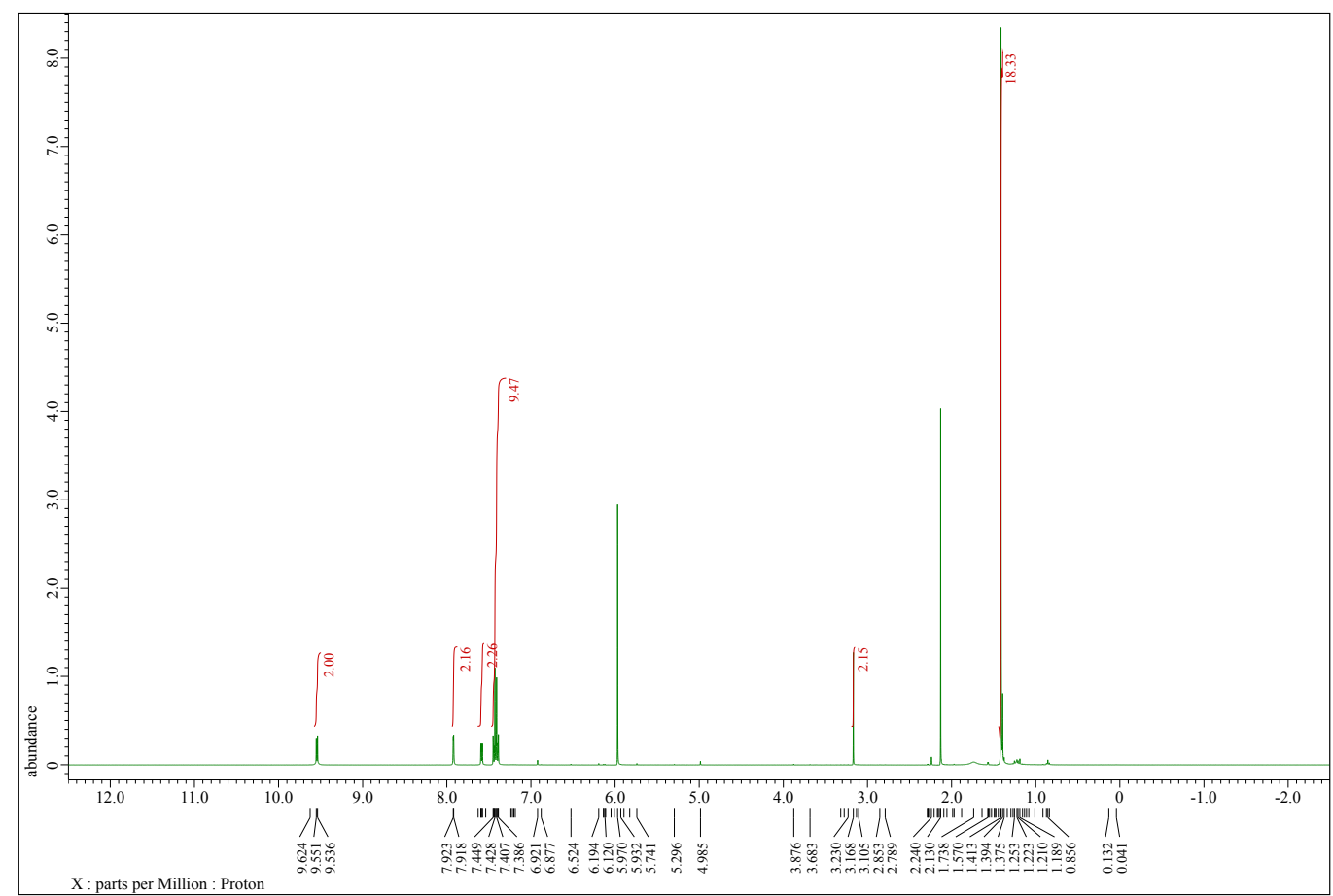

Figure S12. ${ }^{1} \mathrm{H}$ NMR spectrum $\left(400 \mathrm{MHz}, \mathrm{CDCl}_{2} \mathrm{CDCl}_{2}\right)$ of $\mathbf{M 1}$. 


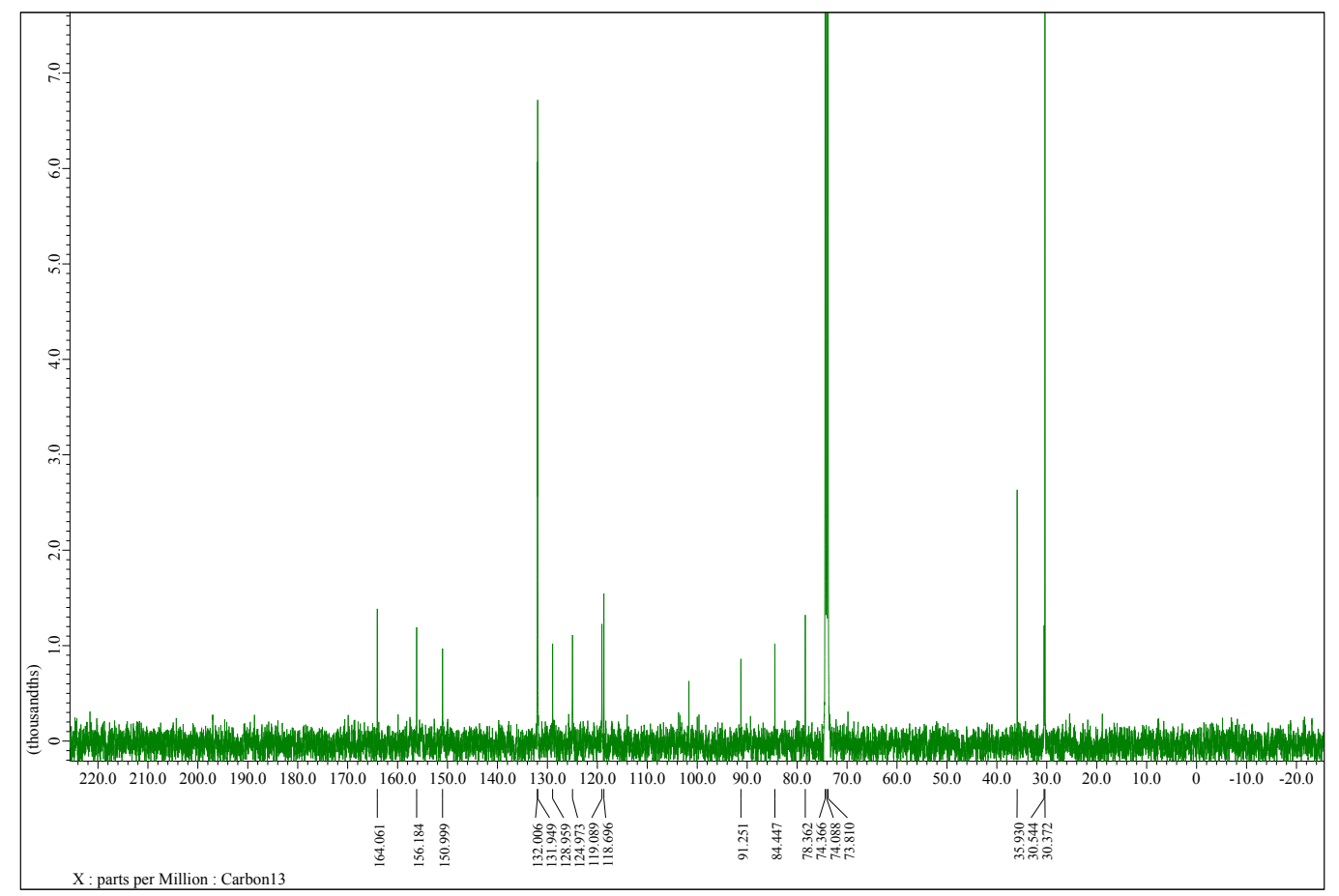

Figure S13. ${ }^{13} \mathrm{C}$ NMR spectrum $\left(100 \mathrm{MHz}, \mathrm{CDCl}_{2} \mathrm{CDCl}_{2}\right)$ of $\mathbf{M 1}$. 


\section{IR Spectra}

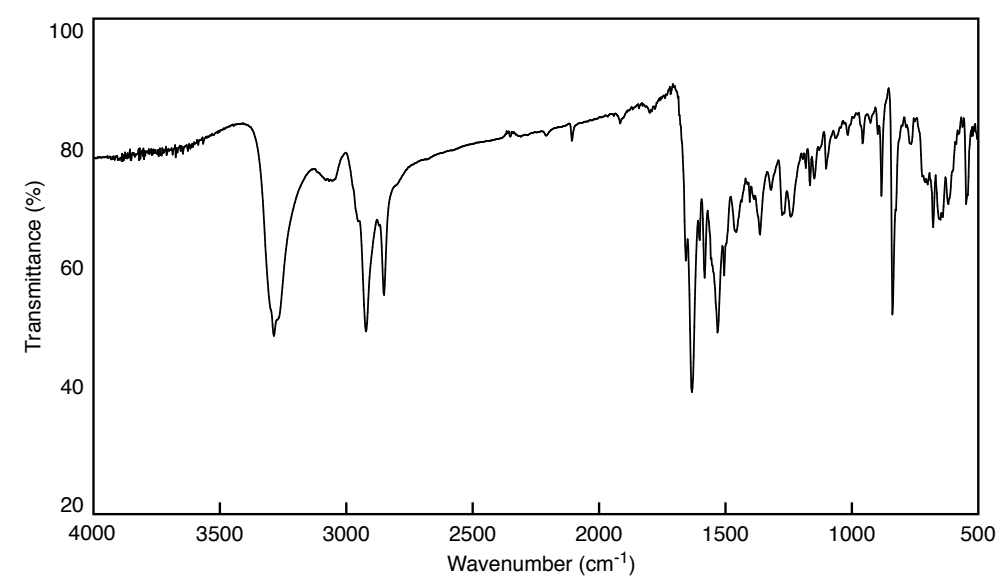

Figure S14. IR spectrum of 2.

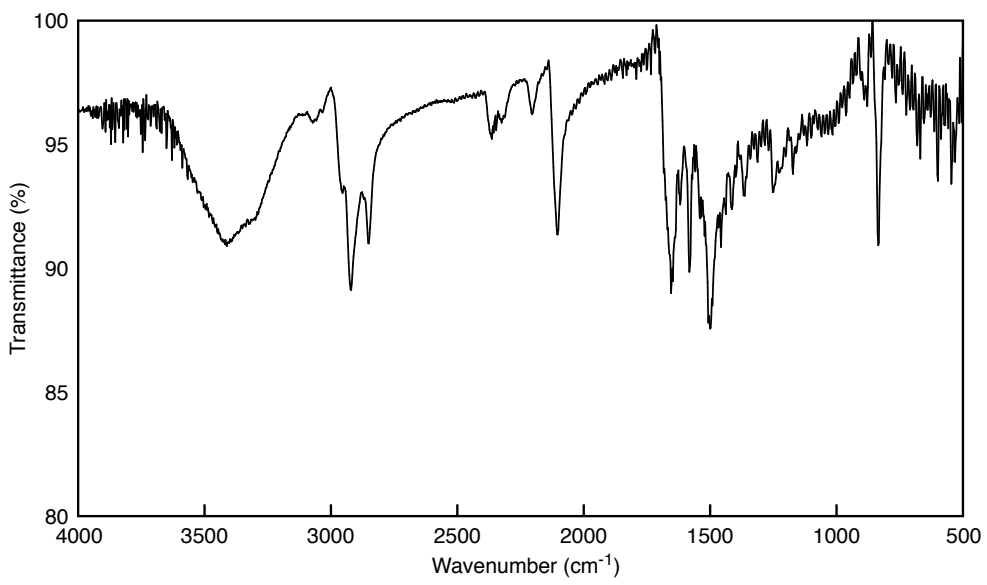

Figure S15. IR spectrum of poly(1a-2).

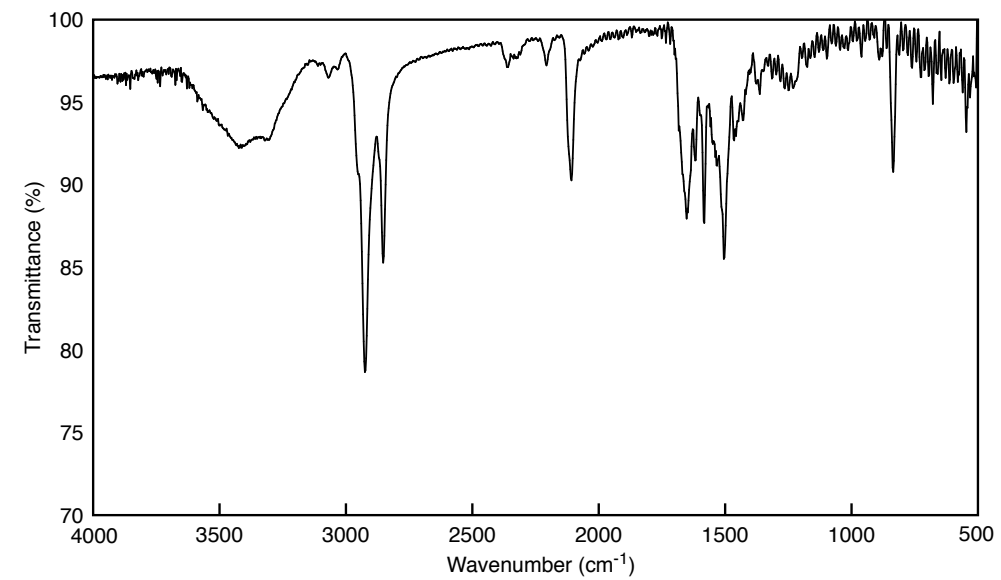

Figure S16. IR spectrum of poly(1b-2). 


\section{SEC Traces}

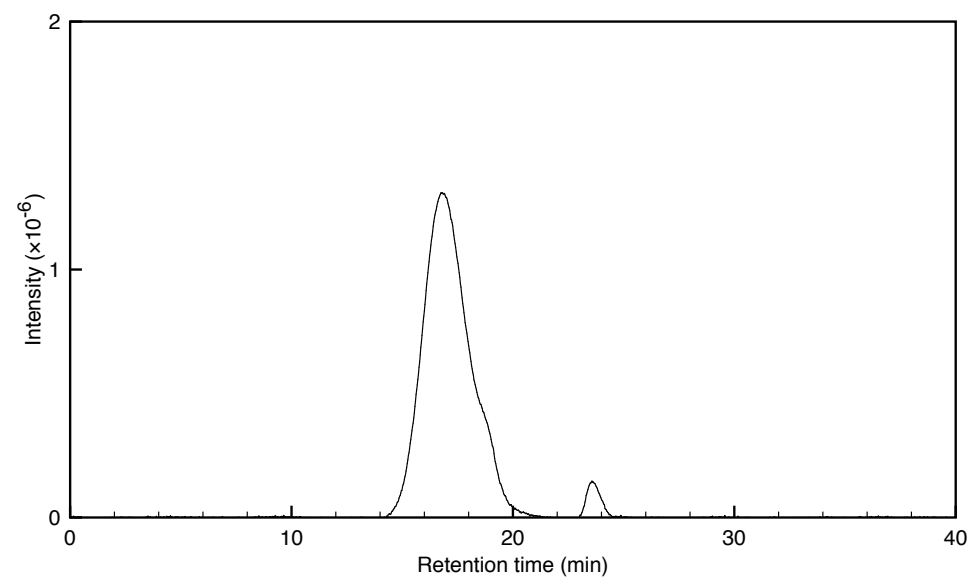

Figure S17. SEC trace of poly(1a-2) (Sample: run 1 in Table 1). The peak at 23 min is unrelated with the polymer (See Figure S20).

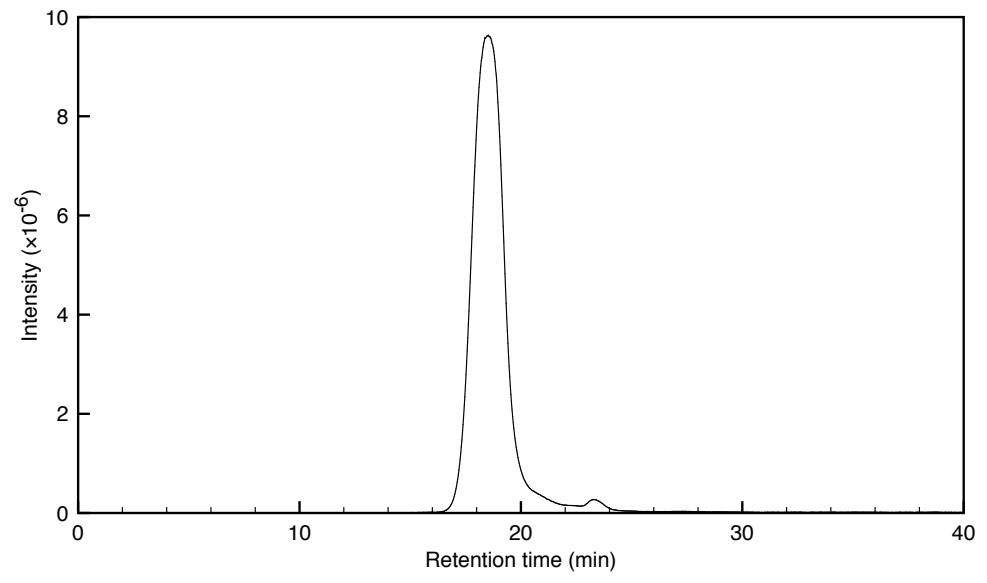

Figure S18. SEC trace of poly(1a-2) (Sample: run 2 in Table 1). The peak at 23 min is unrelated with the polymer (See Figure S20). 


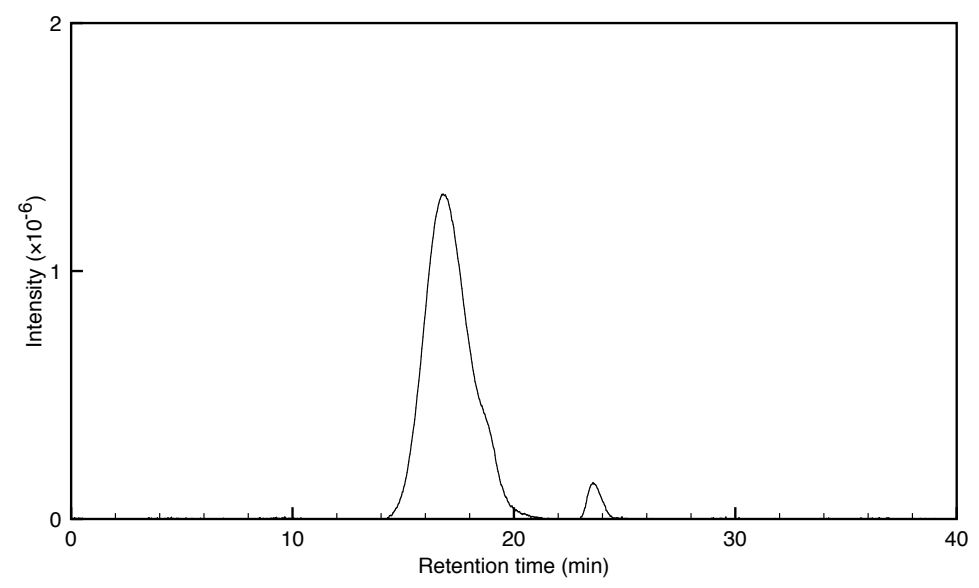

Figure S19. SEC trace of soluble part of poly(1)-2) (Sample: run 4 in Table 1). The peak at $23 \mathrm{~min}$ is unrelated with the polymer (See Figure S20).

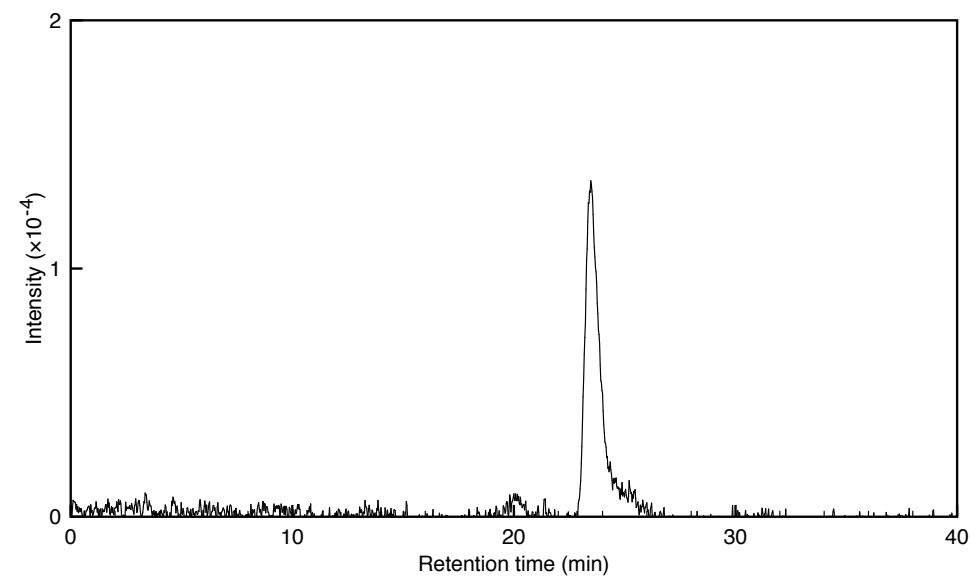

Figure S20. SEC trace of a blank sample. 


\section{Optical Properties}

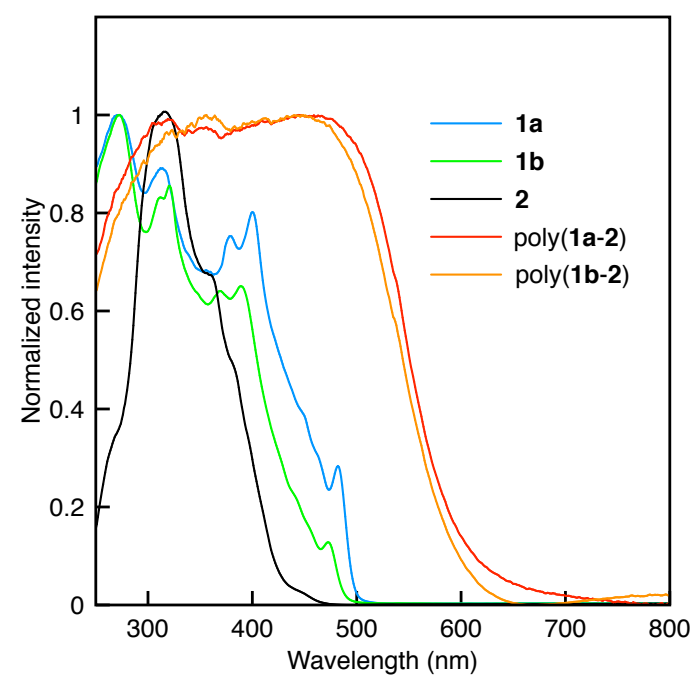

Figure S21. UV-vis diffuse reflectance spectra of 1a, 1b, 2, poly(1a-2) and poly(1)-2). The reflectance values of these spectra were converted to the corresponding absorption values by the Kubelka-Munk equation. Samples of the polymers: runs 1 and 3 in Table 1.

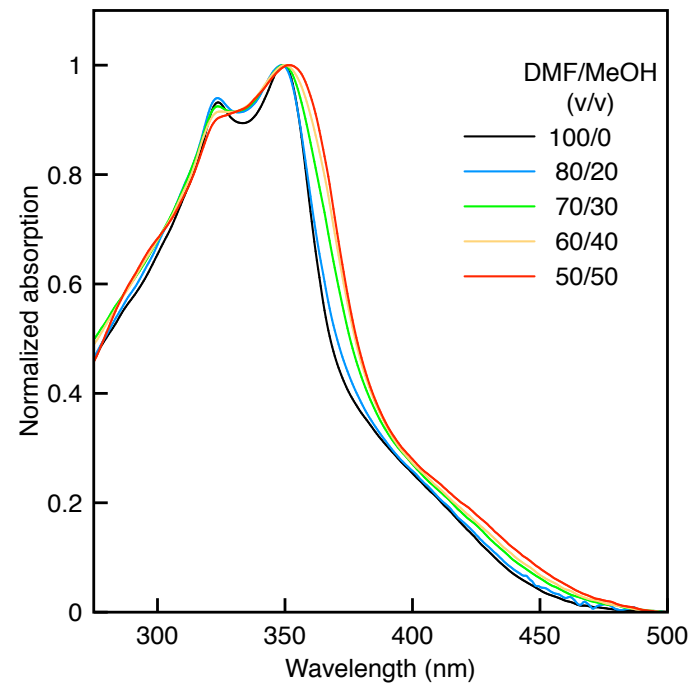

Figure S22. Normalized UV-vis absorption spectra of poly(1a-2) measured in $\mathrm{DMF} / \mathrm{MeOH}=$ $100 / 0-50 / 50(\mathrm{v} / \mathrm{v}, c=0.01 \mathrm{mM})$ at $20^{\circ} \mathrm{C}$. The $\mathrm{UV}$-vis absorption intensities are normalized at the absorption maxima. Sample: run 1 in Table 1. 


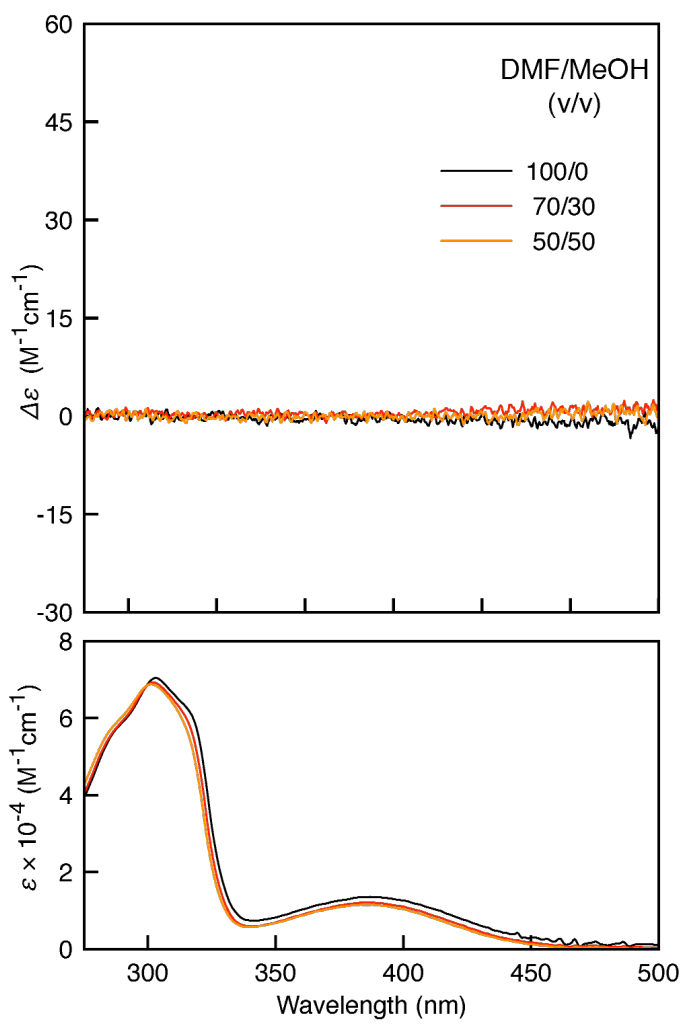

Figure S23. CD and UV-vis absorption spectra of $\mathbf{M 1}$ measured in DMF/MeOH $=100 / 0,70 / 30$ and $50 / 50(\mathrm{v} / \mathrm{v}, c=0.01 \mathrm{mM})$.

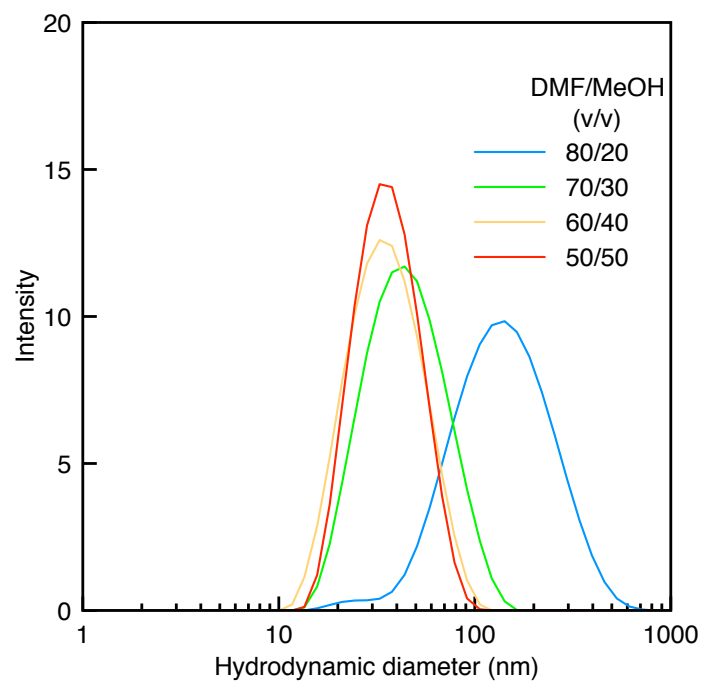

Figure S24. DLS chart of poly (1a-2) measured in $\mathrm{DMF} / \mathrm{MeOH}$ with various compositions $(c=$ $0.01 \mathrm{mM})$ at $20^{\circ} \mathrm{C}$. Sample: run 1 in Table 1. 


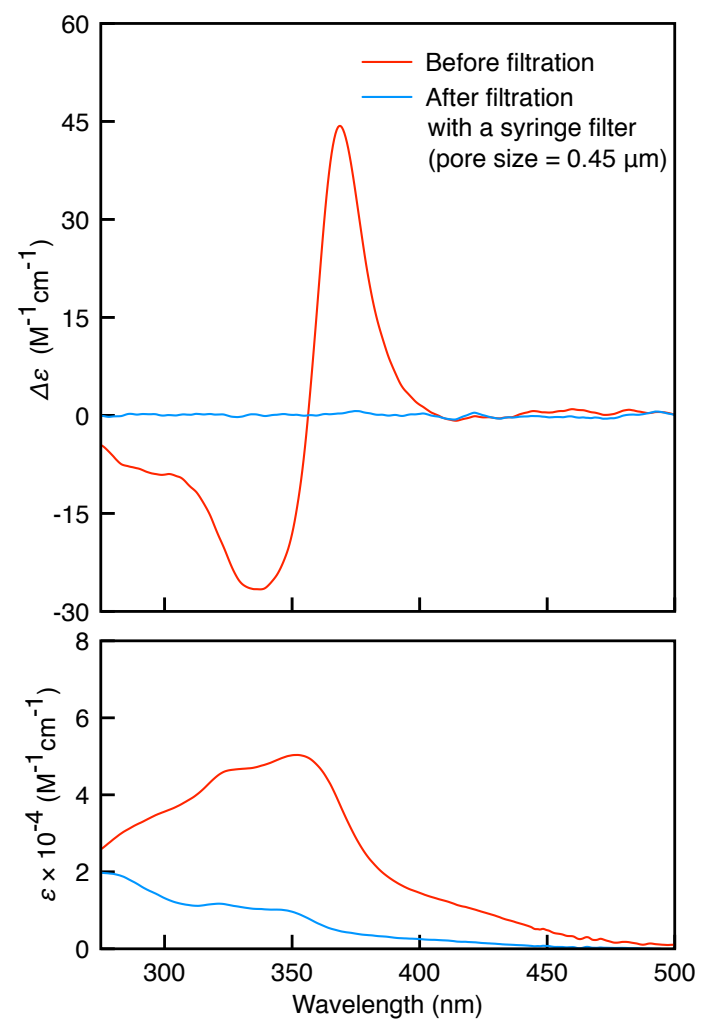

Figure S25. CD and UV-vis absorption spectra of poly(1a-2) measured in DMF/MeOH $=50 / 50$ $(\mathrm{v} / \mathrm{v}, c=0.01 \mathrm{mM})$ at $20^{\circ} \mathrm{C}$ before and after filtration with a syringe filter (ADVANTEC DISMIC03JP, pore size: $0.45 \mu \mathrm{m})$. Sample: run 1 in Table 1. 

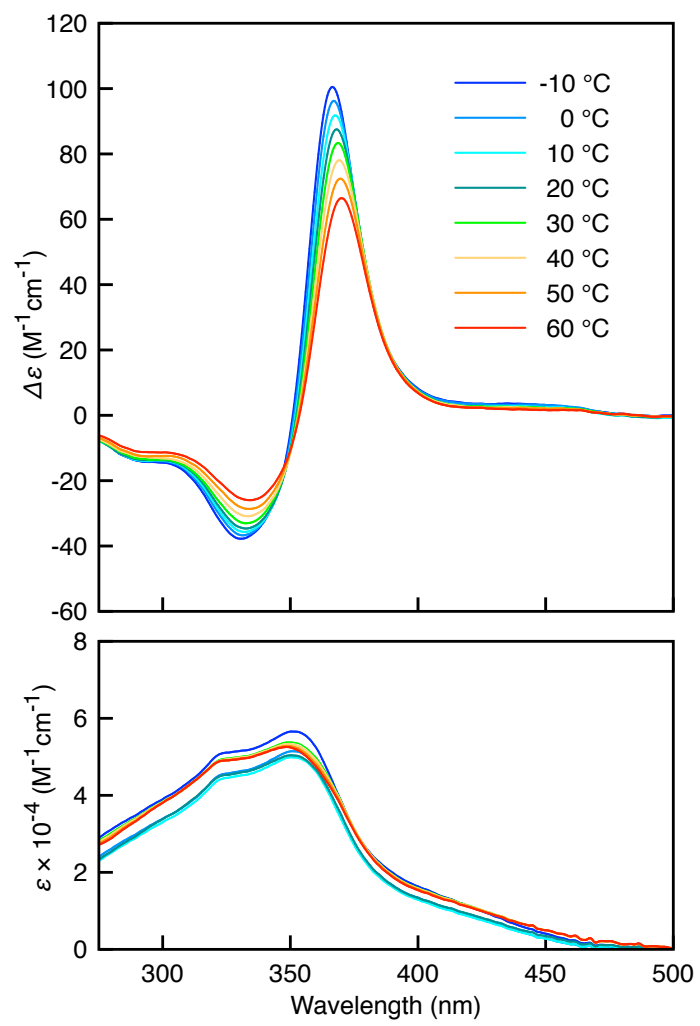

Figure S26. CD and UV-vis absorption spectra of poly(1a-2) measured in $\mathrm{DMF} / \mathrm{MeOH}=50 / 50$ $(\mathrm{v} / \mathrm{v}, c=0.01 \mathrm{mM})$ at various temperatures. The sample solution was first cooled to $-10{ }^{\circ} \mathrm{C}$, then heated up to $60^{\circ} \mathrm{C}$. Sample: run 1 in Table 1 . 


\section{POM Images}

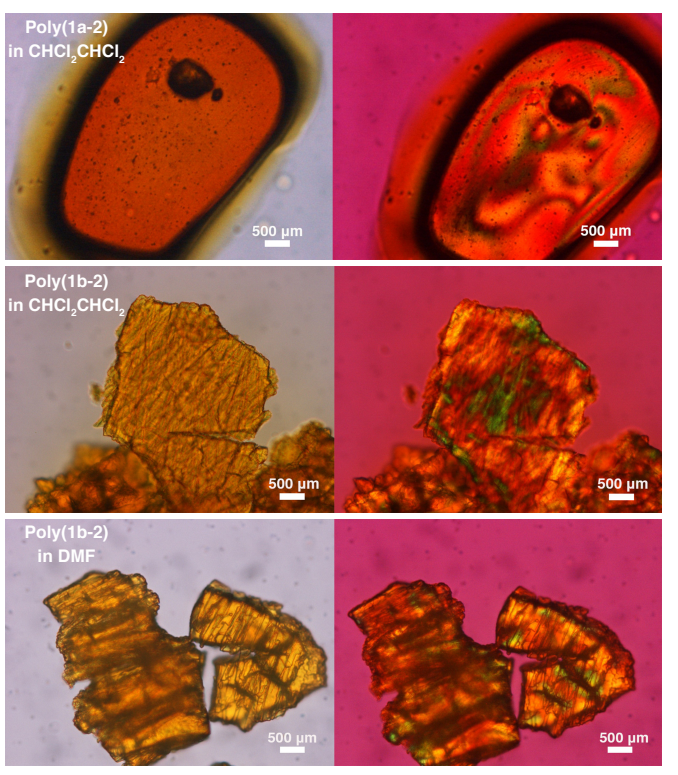

Figure S27. POM images of poly(1a-2) and poly(1b-2) measured in $\mathrm{CHCl}_{2} \mathrm{CHCl}_{2}$ and $\mathrm{DMF}$ without a polarizer (left), with a cross-polarizer (right). Samples: runs 1 and 3 in Table 1. 


\section{DFT Calculations}

\section{Monomers 1a, 2 and Poly(1a-2)-Model}
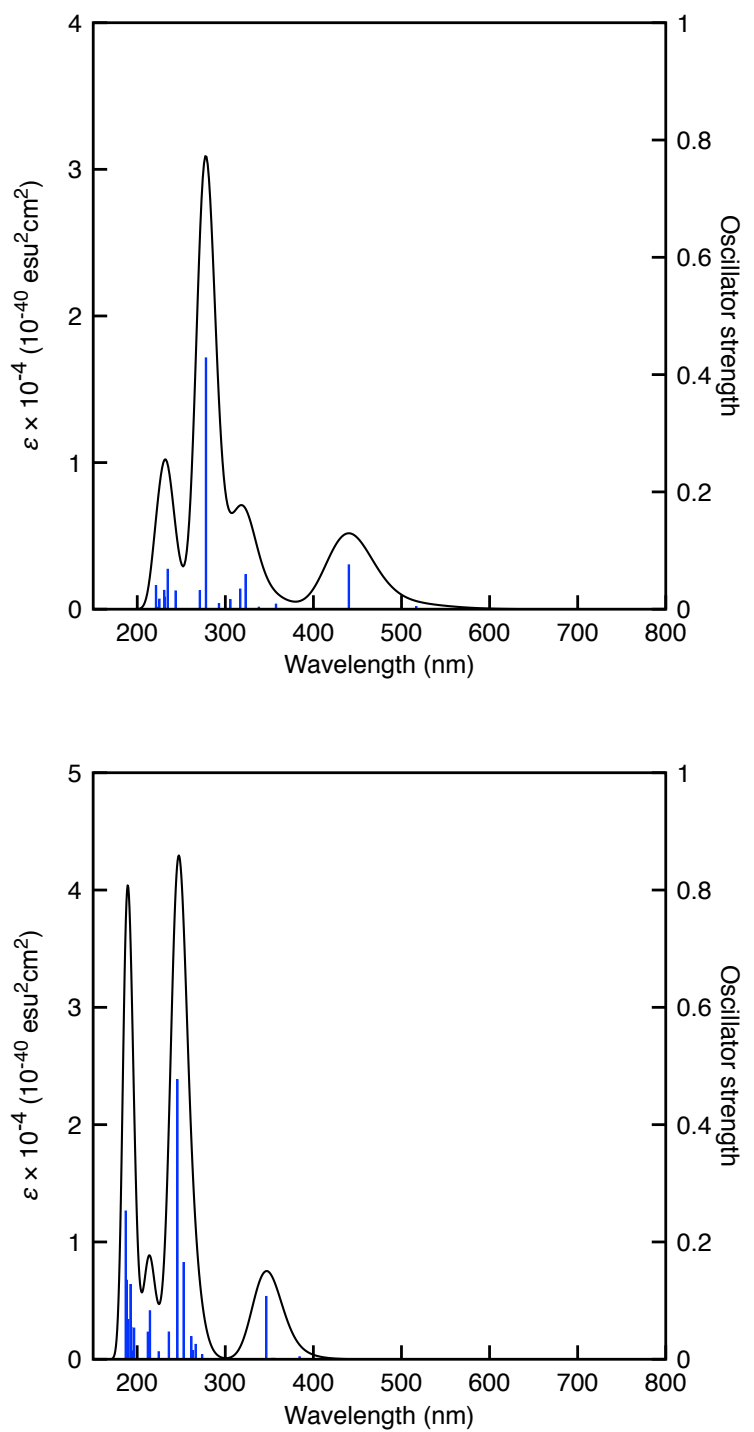

Figure S28. Solid black curves: UV-vis absorption spectra of 1a simulated by the TD-DFT method [top: M06, bottom: $\omega$ B97XD/6-31G* $(\mathrm{C}, \mathrm{H}, \mathrm{N})$, LANL2DZ $(\mathrm{Pt})$ ], nstates $=40$, peak half-width at half height $=0.2 \mathrm{eV}$. Vertical blue lines represent oscillator strength. 

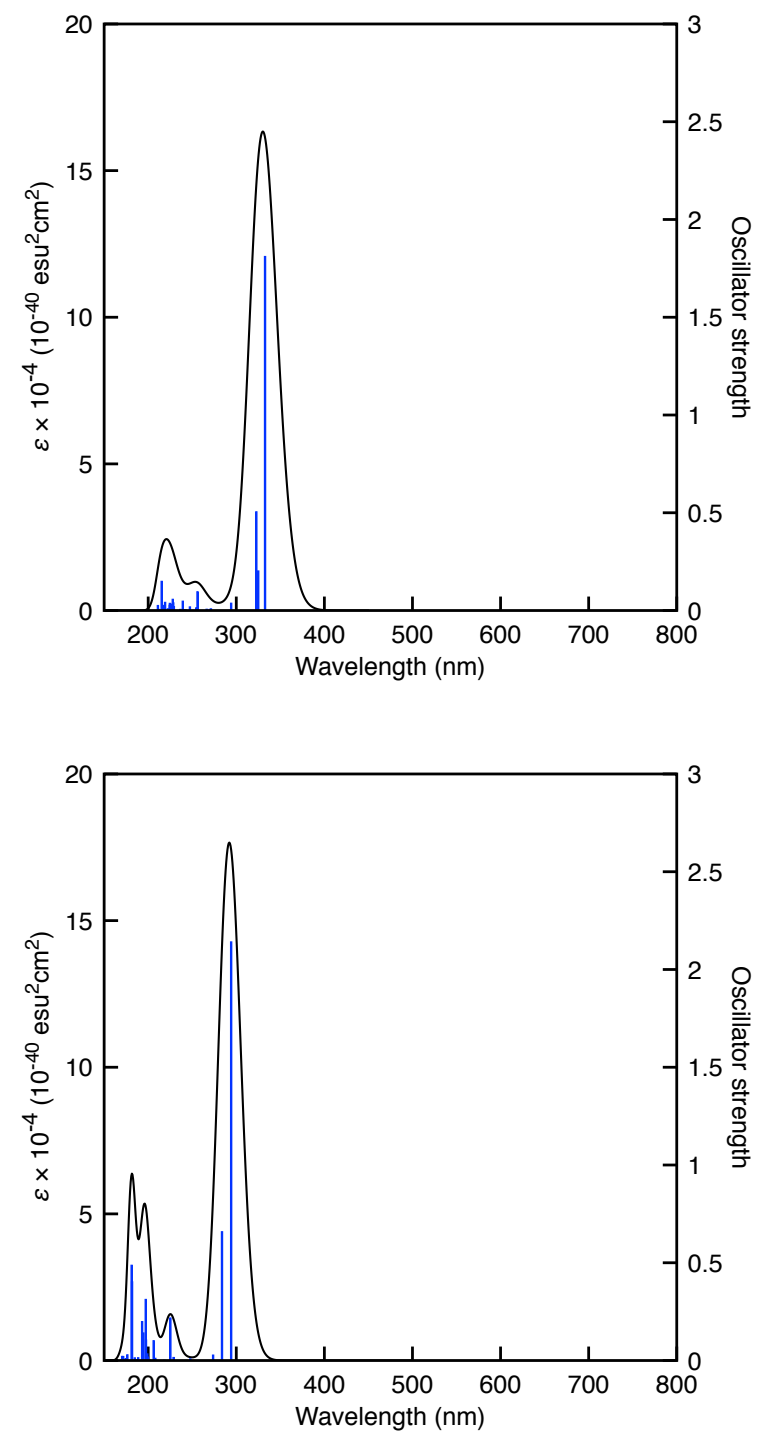

Figure S29. Solid black curves: UV-vis absorption spectra of 2 simulated by the TD-DFT method [top: M06, bottom: $\omega$ B97XD/6-31G* $(\mathrm{C}, \mathrm{H}, \mathrm{N})$, LANL2DZ (Pt)], nstates $=40$, peak half-width at half height $=0.2 \mathrm{eV}$. Vertical blue lines represent oscillator strength. 

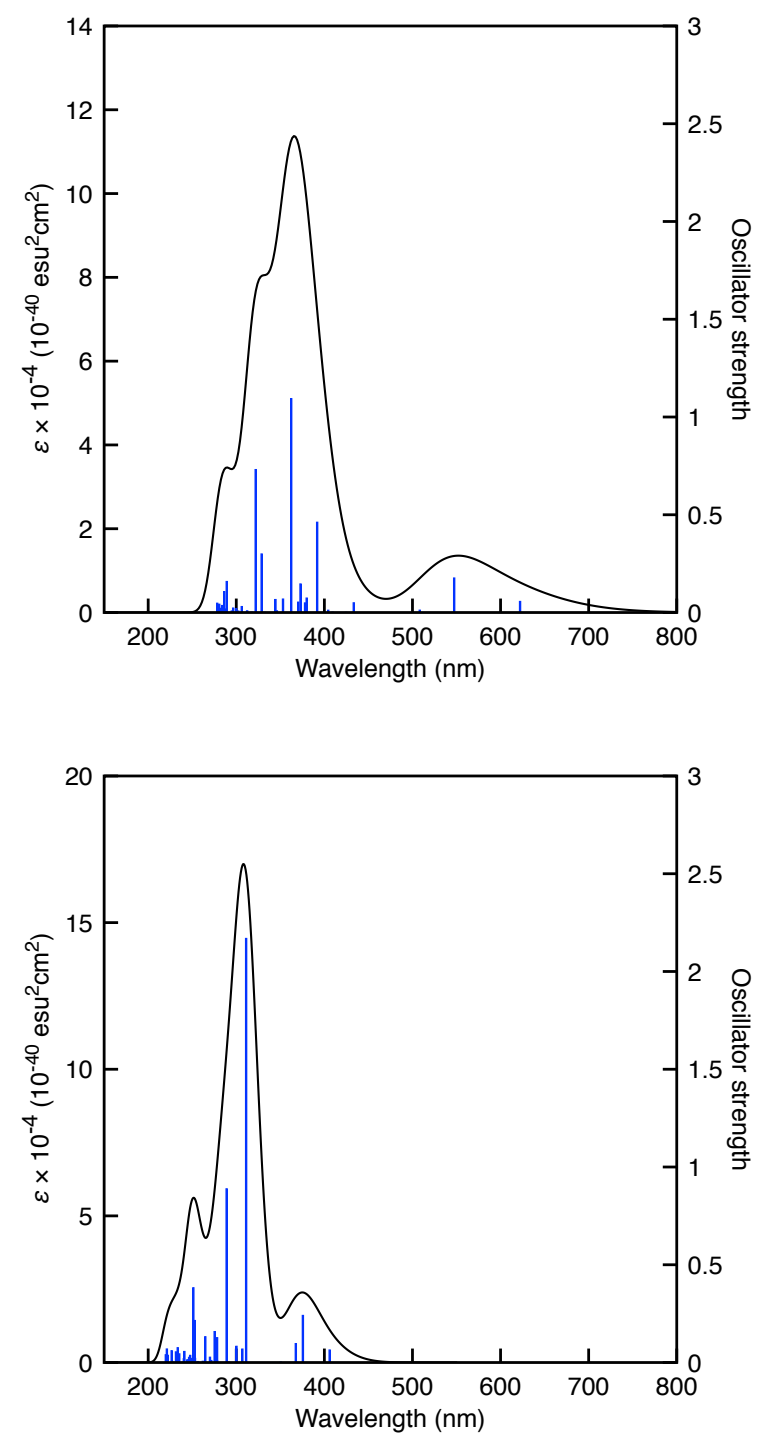

Figure S30. Solid black curves: UV-vis absorption spectra of poly(1a-2)-model simulated by the TD-DFT method [top: M06, bottom: $\omega$ B97XD/6-31G* (C, H, N), LANL2DZ (Pt)], nstates $=40$, peak half-width at half height $=0.2 \mathrm{eV}$. Vertical blue lines represent oscillator strength. 

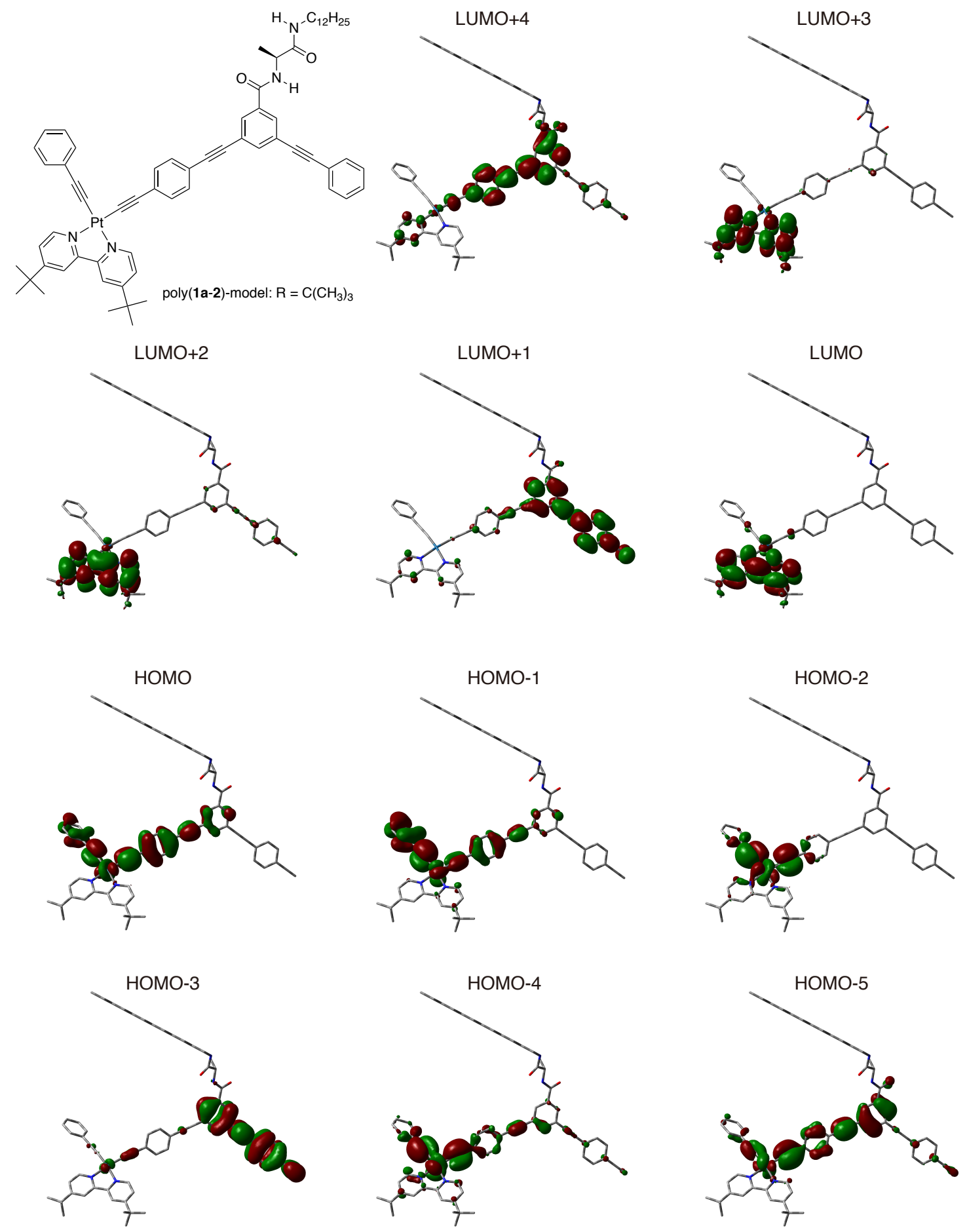

Figure S31. Shapes of HOMO-5 (MO \#266)-HOMO (MO\#271) and LUMO (MO\#272)LUMO+4 (MO\#277) of a conformer of poly(1a-2)-model obtained by the TD-DFT method [ $\omega$ B97XD/6-31G* $(\mathrm{C}, \mathrm{H}, \mathrm{N})$, LANL2DZ (Pt)]. The geometries were fully optimized by the DFT method with the same functional and basis sets. 
Table S1. Excitation Energies, Oscillator Strength, CI Coefficient, and Assignment of the Excited-states of Poly(1a-2)-model ${ }^{a}$

\begin{tabular}{cccccc}
\hline $\begin{array}{c}\text { excited } \\
\text { state }^{b}\end{array}$ & $\begin{array}{c}\text { energy } \\
\text { eV }(\mathrm{nm})\end{array}$ & $f^{c}$ & transition $^{d}$ & CI coefficient $^{e}$ & assignment $^{f}$ \\
\hline 2 & 3.30 & 0.2413 & HOMO-1 $\rightarrow$ LUMO & 0.49977 & MLCT/LLCT \\
& $(375)$ & & $\begin{array}{c}\text { HOMO-4 } \rightarrow \text { LUMO } \\
\text { HOMO } \rightarrow \text { LUMO }\end{array}$ & 0.28984 & 0.22353 \\
& & & HOMO $\rightarrow$ LUMO+4 & 0.45065 & $\pi-\pi^{*}$ \\
5 & 3.98 & 2.1695 & HOMO-1 $\rightarrow$ LUMO+4 & 0.23534 & transition/LLCT \\
& $(311)$ & & HOMO $\rightarrow$ LUMO+1 & 0.19886 & $\pi-\pi^{*}$ \\
9 & & & HOMO-3 $\rightarrow$ LUMO+1 & 0.53722 & transition/LLCT \\
& 4.29 & 0.889 & HOMO $\rightarrow$ LUMO+2 & 0.23568 & \\
& $(289)$ & & HOMO $\rightarrow$ LUMO+4 & 0.16431 & \\
\hline
\end{tabular}

${ }^{a}$ Calculated by the TD-DFT method $\left[\omega B 97 X D / 6-31 G^{*}(\mathrm{C}, \mathrm{H}, \mathrm{N})\right.$, LANL2DZ (Pt)] with the conformer shown in Figure S31. ${ }^{b}$ The excited states with oscillator strength values $(f)$ larger than 0.1 are presented. ${ }^{c}$ Oscillator strength values. ${ }^{d}$ The main components are presented. ${ }^{e} \mathrm{CI}$ coefficients are in absolute values. ${ }^{f} \mathrm{MLCT}=$ metal-to-ligand charge transfer, LLCT $=$ ligand-toligand charge transfer. 
Association Models
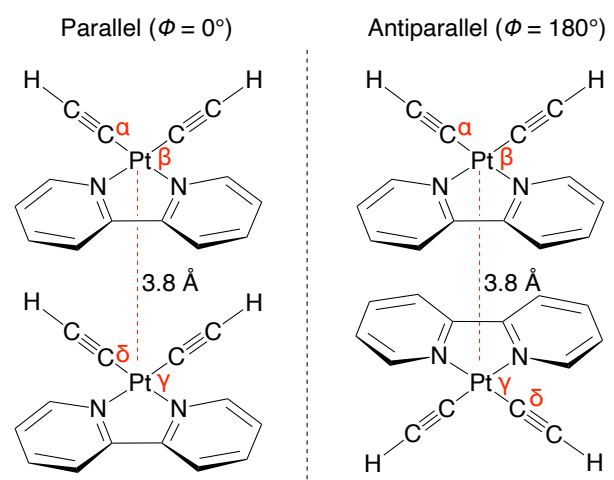

Figure S32. Initial conformers of parallel $\left(\Phi=0^{\circ}\right)$ and antiparallel $\left(\Phi=180^{\circ}\right) \mathrm{Pt}(\mathrm{bpy})(\mathrm{C} \equiv \mathrm{C}-\mathrm{H})_{2}$ •. $\mathrm{Pt}(\mathrm{bpy})(\mathrm{C} \equiv \mathrm{C}-\mathrm{H})_{2}$ association models, wherein the dihedral angle $\Phi$ is defined with $\mathrm{C}_{\alpha}-\mathrm{Pt}_{\beta}-\mathrm{Pt}_{\gamma}$ $\mathrm{C}_{\delta}$. 

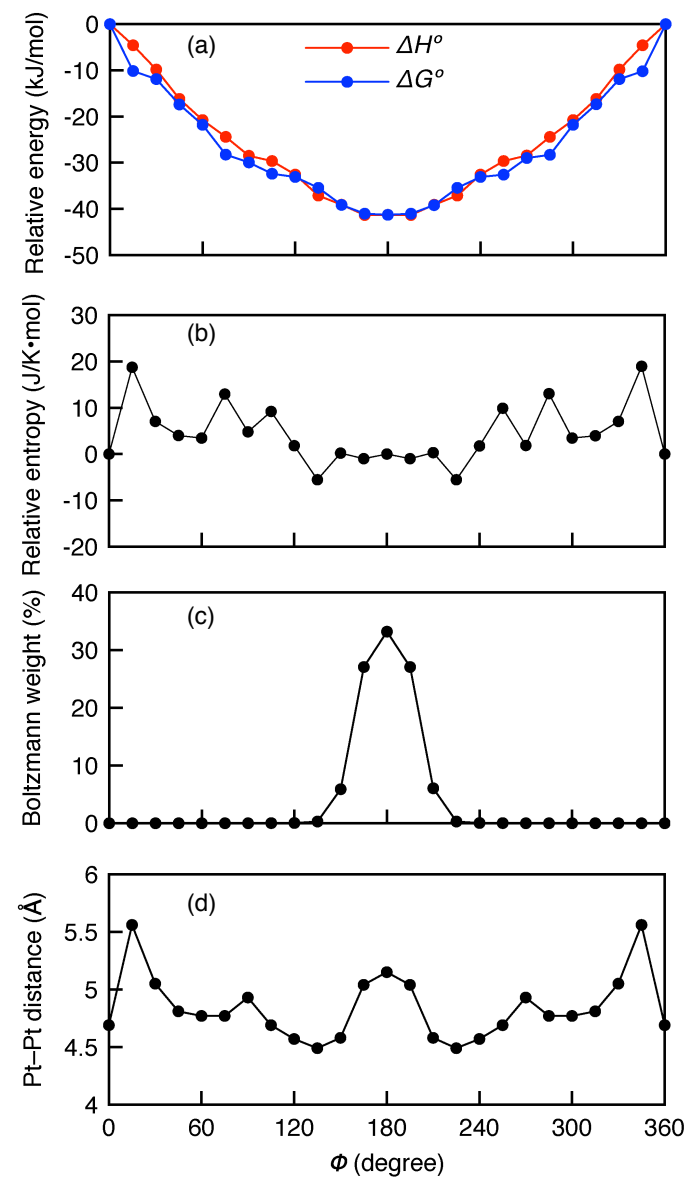

Figure S33. Relationships between the dihedral angle $\Phi, \mathrm{C}_{\alpha}-\mathrm{Pt}_{\beta}-\mathrm{Pt}_{\gamma}-\mathrm{C}_{\delta}$ of $\mathrm{Pt}(\mathrm{bpy})(\mathrm{C} \equiv \mathrm{C}-\mathrm{H})_{2} \bullet \bullet$ $\operatorname{Pt}($ bpy $)(\mathrm{C} \equiv \mathrm{C}-\mathrm{H})_{2}$ association models (see Figure S32) and (a) $\Delta H^{\circ}$ and $\Delta G^{\circ}$ at $298 \mathrm{~K}$ per unit relative to the values of conformer of $\Phi=0^{\circ}$, (b) $\Delta S^{\circ}$ per unit relative to the value of the conformer with $\Phi=0^{\circ}$, (c) Boltzmann weight distribution, (d) interatomic distance between $\mathrm{Pt}_{\beta}$ and $\mathrm{Pt}_{\gamma}$ calculated by the DFT method [M06/6-31G* (C, H, N), LANL2DZ (Pt)]. 

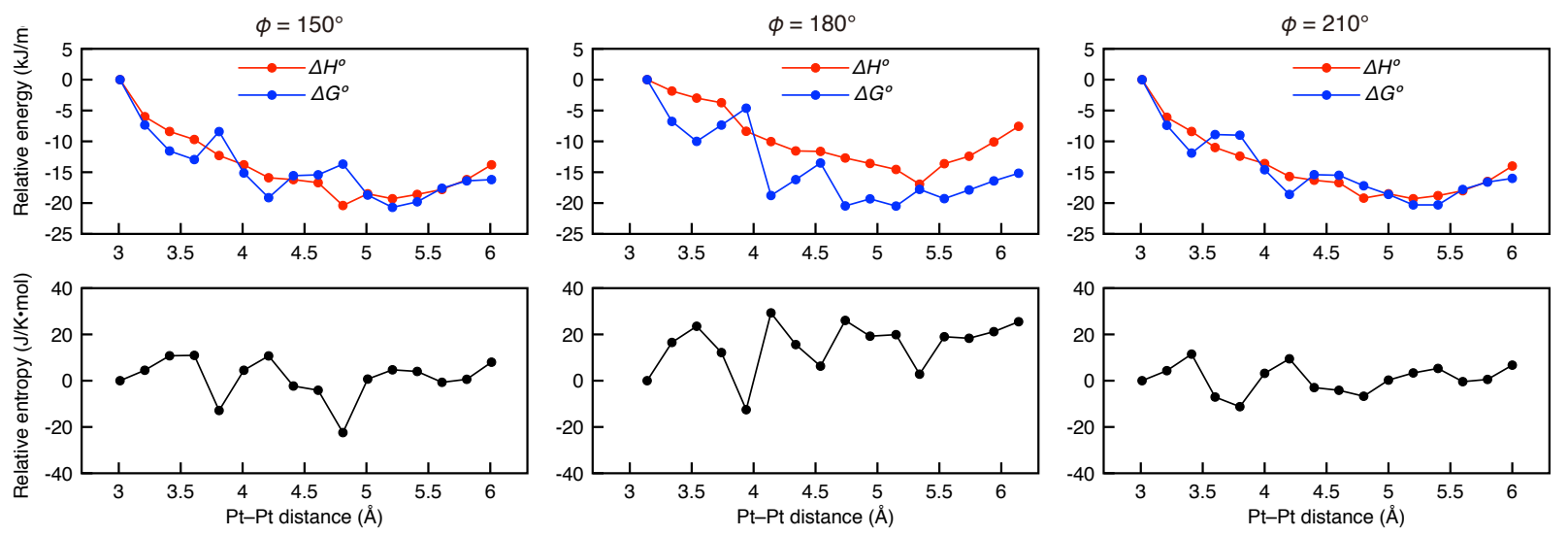

Figure S34. Relationships between the Pt-Pt distance of $\mathrm{Pt}(\mathrm{bpy})(\mathrm{C} \equiv \mathrm{C}-\mathrm{H})_{2} \cdots \operatorname{Pt}(\mathrm{bpy})(\mathrm{C} \equiv \mathrm{C}-\mathrm{H})_{2}$ association model and $\Delta H^{\circ}, \Delta S^{\circ}$ and $\Delta G^{\circ}$ at $298 \mathrm{~K}$ per unit relative to the values of conformer with $\Phi=150^{\circ}, 180^{\circ}$ and $210^{\circ}$ calculated by the DFT method [M06/6-31G* $(\mathrm{C}, \mathrm{H}, \mathrm{N})$, LANL2DZ (Pt)].
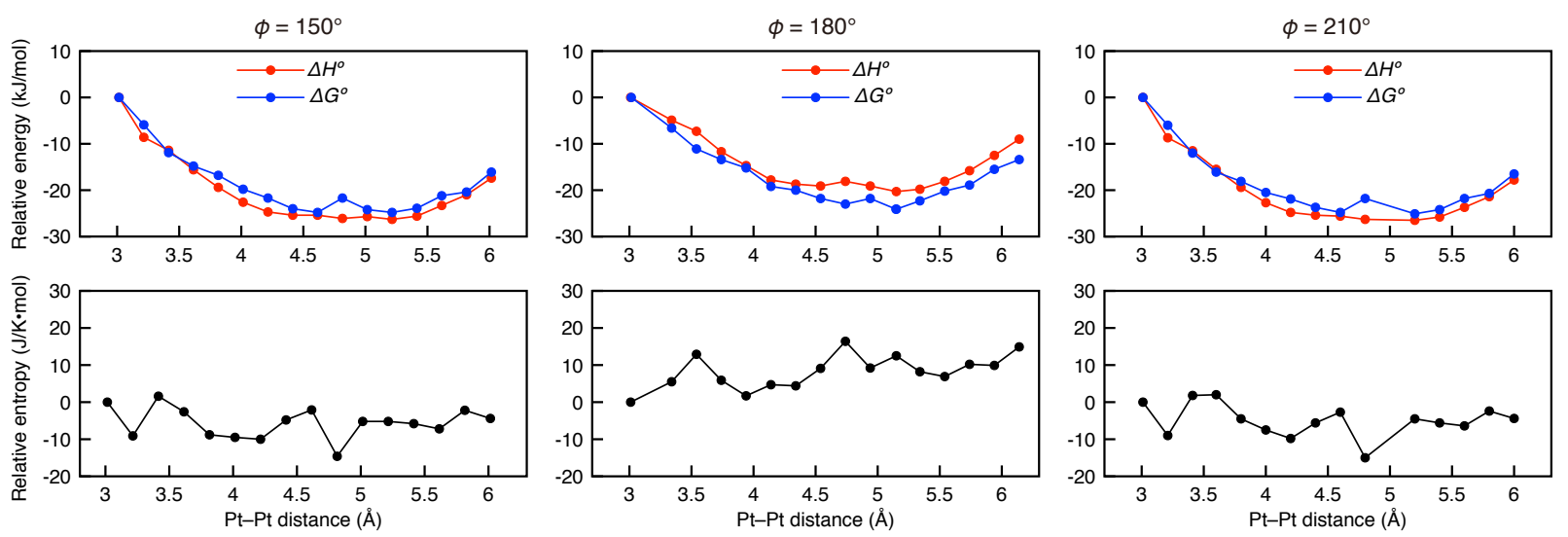

Figure S35. Relationships between the Pt-Pt distance of $\mathrm{Pt}(\mathrm{bpy})(\mathrm{C} \equiv \mathrm{C}-\mathrm{H})_{2} \cdots \operatorname{Pt}(\mathrm{bpy})(\mathrm{C} \equiv \mathrm{C}-\mathrm{H})_{2}$ association models and $\Delta H^{\circ}, \Delta S^{\circ}$ and $\Delta G^{\circ}$ at $298 \mathrm{~K}$ per unit relative to the values of conformer with $\Phi=150^{\circ}, 180^{\circ}$ and $210^{\circ}$ calculated by the DFT method $\left[\omega \mathrm{B} 97 \mathrm{XD} / 6-31 \mathrm{G}^{*}(\mathrm{C}, \mathrm{H}, \mathrm{N})\right.$, LANL2DZ (Pt)] 

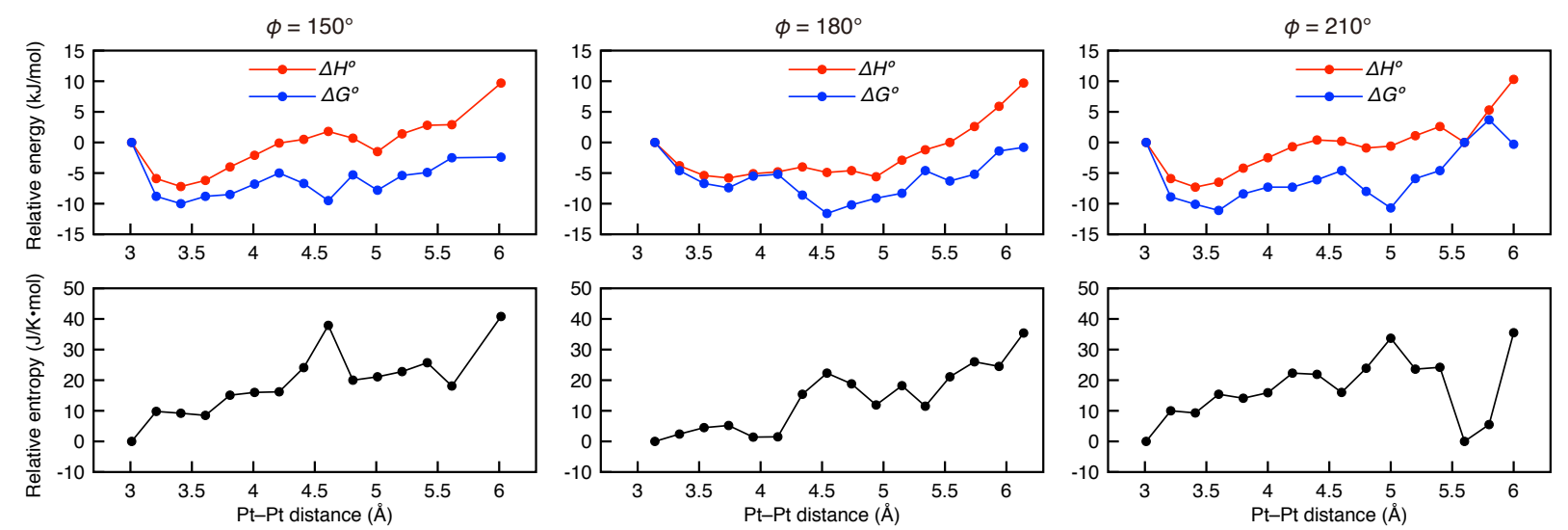

Figure S36. Relationships between the $\mathrm{Pt}-\mathrm{Pt}$ distance of $\mathrm{Pt}(\mathrm{bpy})(\mathrm{C} \equiv \mathrm{C}-\mathrm{Ph})_{2} \bullet \bullet \mathrm{Pt}(\mathrm{bpy})(\mathrm{C} \equiv \mathrm{C}-\mathrm{Ph})_{2}$ association models and $\Delta H^{\circ}, \Delta S^{\circ}$ and $\Delta G^{\circ}$ at $298 \mathrm{~K}$ per unit relative to the values of conformer with $\Phi=150^{\circ}, 180^{\circ}$ and $210^{\circ}$ calculated by the DFT method [M06/6-31G* (C, H, N), LANL2DZ $(\mathrm{Pt})]$.
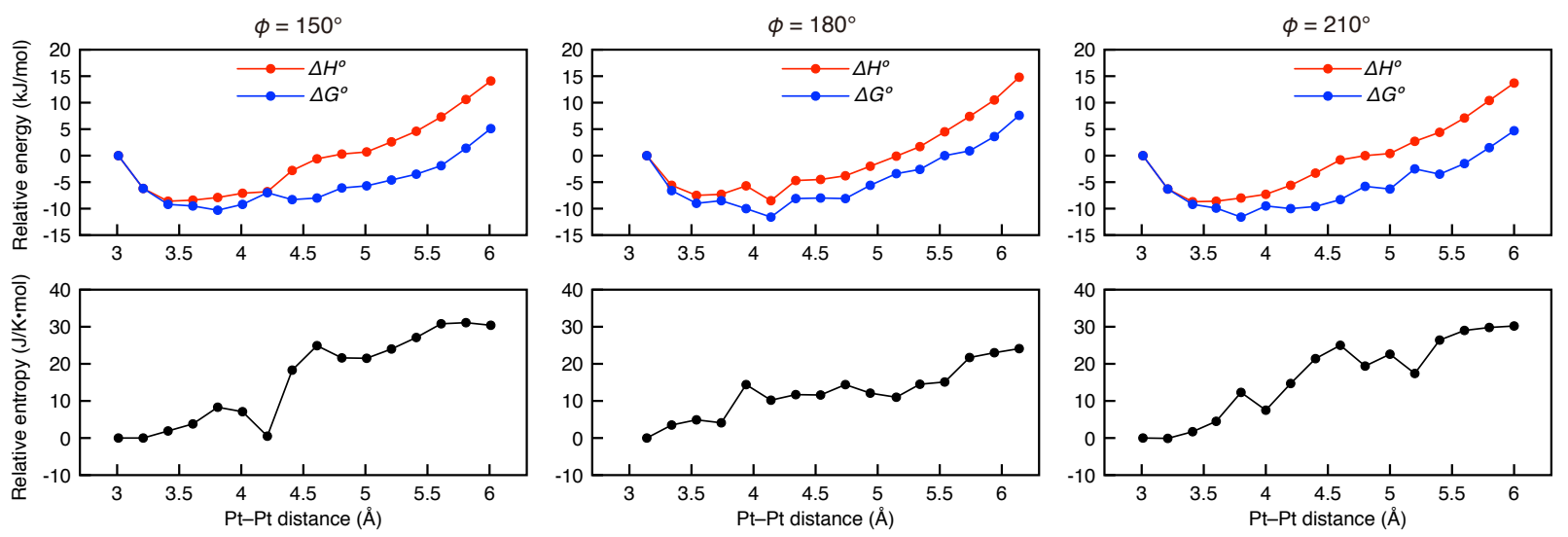

Figure S37. Relationships between the $\mathrm{Pt}-\mathrm{Pt}$ distance of $\mathrm{Pt}(\mathrm{bpy})(\mathrm{C} \equiv \mathrm{C}-\mathrm{Ph})_{2} \bullet \bullet \mathrm{Pt}(\mathrm{bpy})(\mathrm{C} \equiv \mathrm{C}-\mathrm{Ph})_{2}$ association models and $\Delta H^{\circ}, \Delta S^{\circ}$ and $\Delta G^{\circ}$ at $298 \mathrm{~K}$ per unit relative to the values of conformer with $\Phi=150^{\circ}, 180^{\circ}$ and $210^{\circ}$ calculated by the DFT method $\left[\omega \mathrm{B} 97 \mathrm{XD} / 6-31 \mathrm{G}^{*}(\mathrm{C}, \mathrm{H}, \mathrm{N})\right.$, LANL2DZ (Pt)]. 


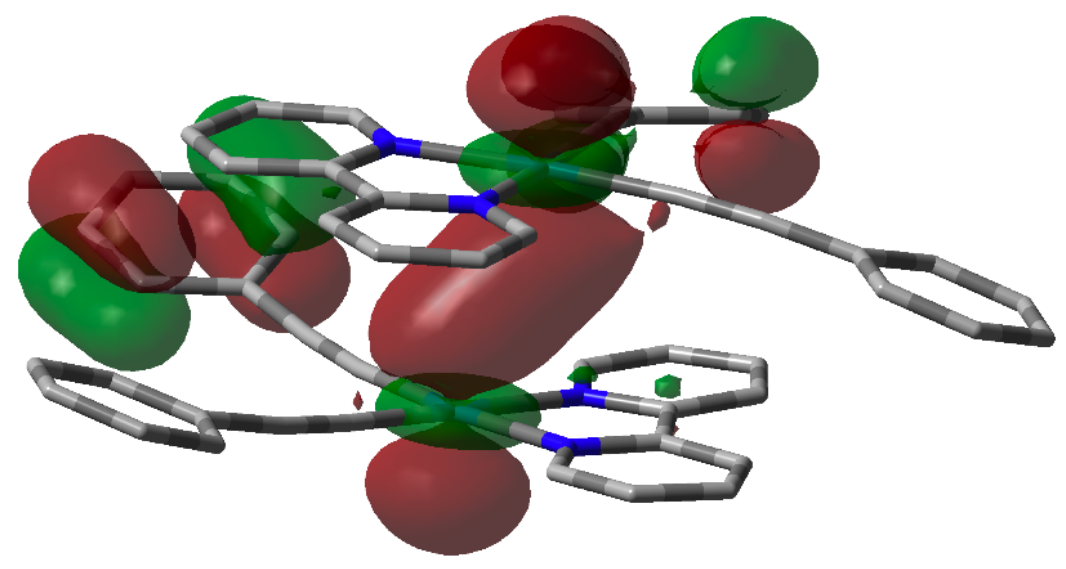

Figure S38. Shape of HOMO-11 of a $\mathrm{Pt}(\mathrm{bpy})(\mathrm{C} \equiv \mathrm{C}-\mathrm{Ph})_{2} \cdots \mathrm{Pt}(\mathrm{bpy})(\mathrm{C} \equiv \mathrm{C}-\mathrm{Ph})_{2}$ association model with $\Phi=210^{\circ}$ obtained by the DFT calculation [ $\omega \mathrm{B} 97 \mathrm{XD} / 6-31 \mathrm{G}^{*}(\mathrm{C}, \mathrm{H}, \mathrm{N})$, LANL2DZ (Pt)]. PtPt distance $=3.6 \AA$ 


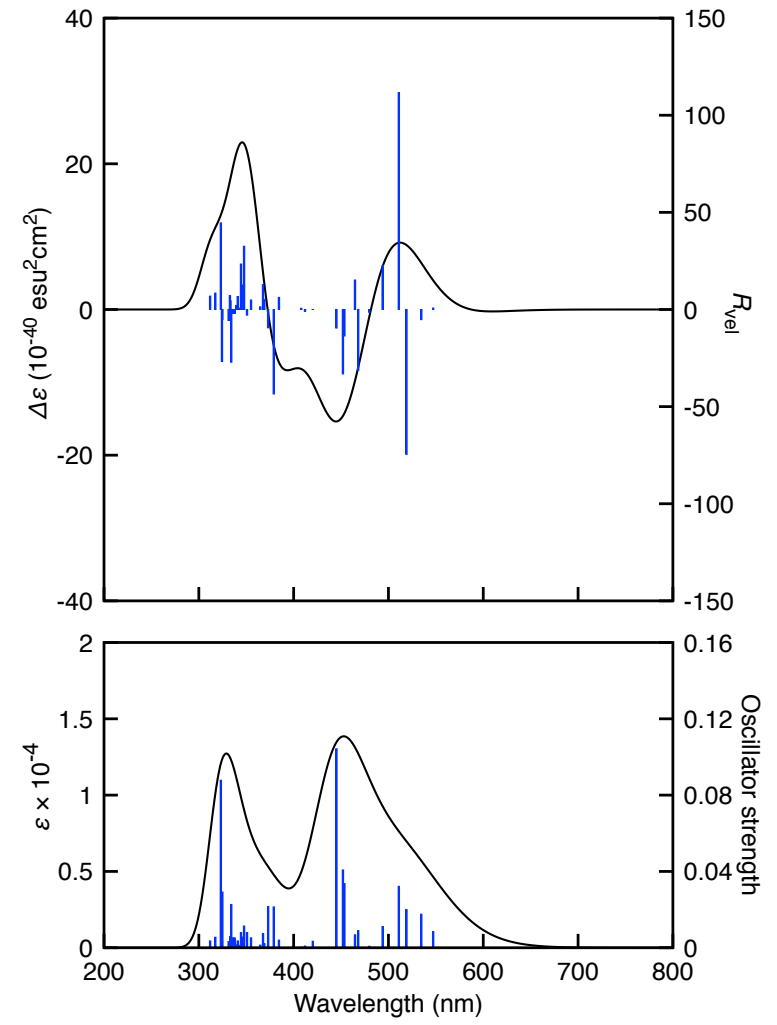

Figure S39. Solid black curves: $\mathrm{CD}$ and UV-vis absorption spectra of a $\mathrm{Pt}(\mathrm{bpy})(\mathrm{C} \equiv \mathrm{C}-\mathrm{Ph})_{2}$ ••• $\operatorname{Pt}($ bpy $)(\mathrm{C} \equiv \mathrm{C}-\mathrm{Ph})_{2}$ association model with $\Phi=210^{\circ}$ simulated by the TD-DFT method [M06/6$\left.31 \mathrm{G}^{*}(\mathrm{C}, \mathrm{H}, \mathrm{N}), \mathrm{LANL} \mathrm{DZ}(\mathrm{Pt})\right]$, nstates $=40$, plotted with peak half-width at half height $=0.2$ eV using Gauss View 6. Vertical blue lines represent $R_{\text {vel }}$ and oscillator strength. 
Simulated CD and UV-Vis Absorption Spectra of $\operatorname{Pt}(b p y)(C \equiv C-H)_{2} \cdots \operatorname{Pt}(b p y)(C \equiv C-H)_{2}$ (bpy = bipyridine)
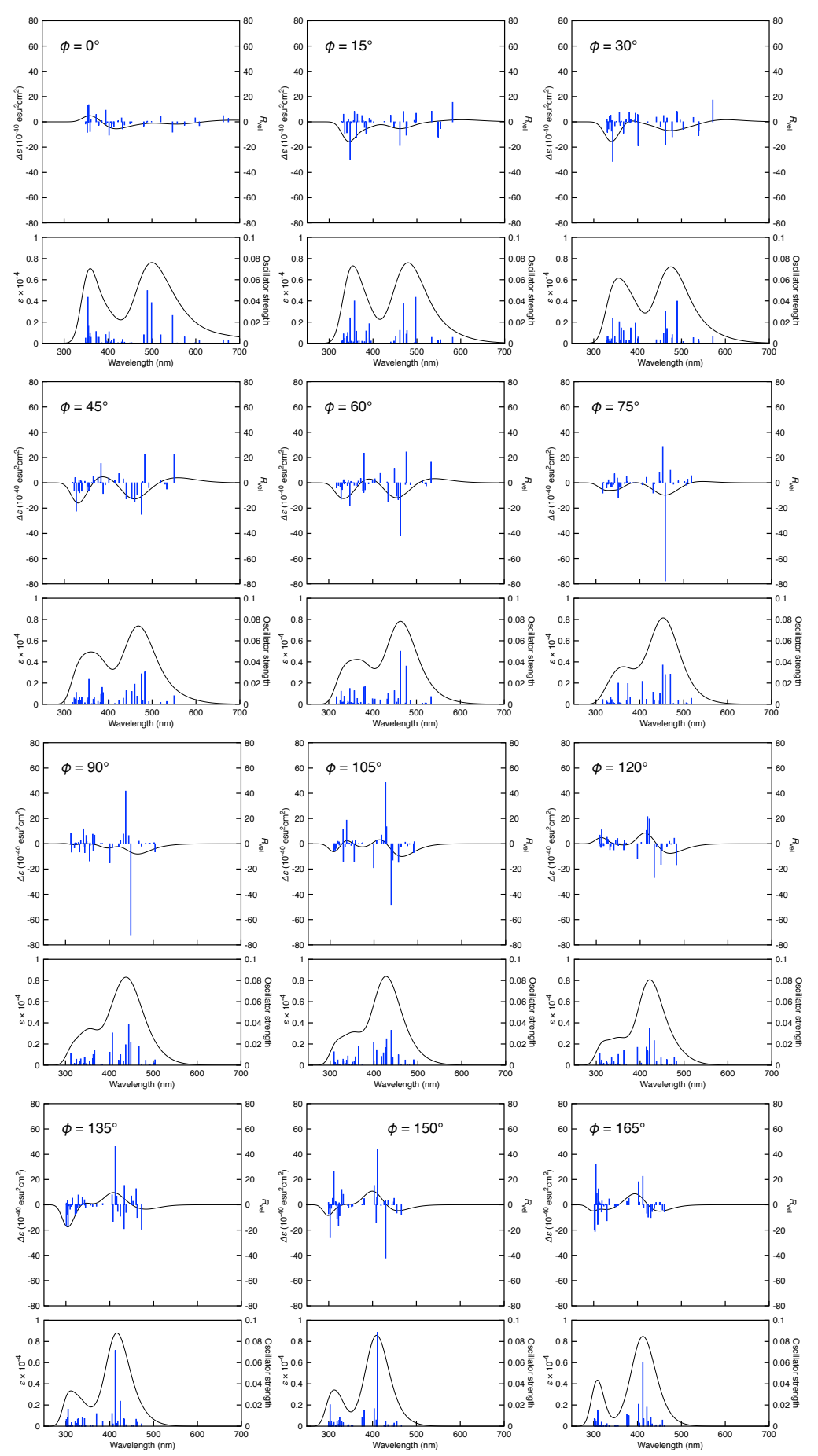

Figure S40. Solid black curves: $\mathrm{CD}$ and UV-vis absorption spectra of conformers of $\mathrm{Pt}(\mathrm{bpy})(\mathrm{C} \equiv \mathrm{C}-$ $\mathrm{H})_{2} \cdots \operatorname{Pt}(\mathrm{bpy})(\mathrm{C} \equiv \mathrm{C}-\mathrm{H})_{2}$ association model with $\Phi=0^{\circ}-165^{\circ}$ at $15^{\circ}$ increment simulated by the TD-DFT method [M06/6-31G* (C, H, N), LANL2DZ (Pt)], nstates = 40, peak half-width at half height $=0.2 \mathrm{eV}$. Vertical blue lines represent $R_{\mathrm{vel}}$ and oscillator strength. 

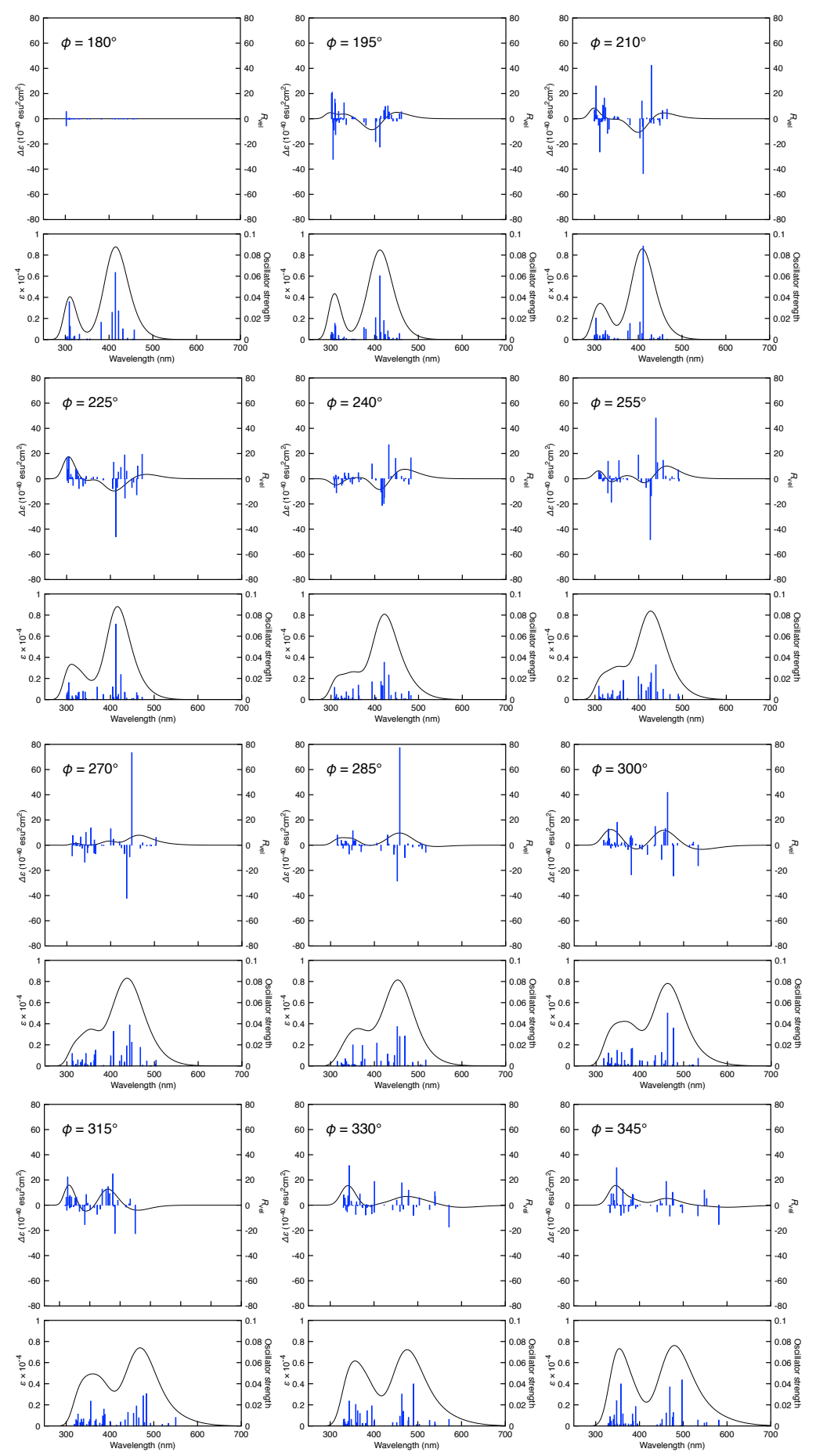

Figure S41. Solid black curves: $\mathrm{CD}$ and UV-vis absorption spectra of conformers of $\mathrm{Pt}(\mathrm{bpy})(\mathrm{C} \equiv \mathrm{C}-\mathrm{H})_{2} \cdots \mathrm{Pt}(\mathrm{bpy})(\mathrm{C} \equiv \mathrm{C}-\mathrm{H})_{2}$ association model with $\Phi=180^{\circ}-345^{\circ}$ at $15^{\circ}$ increment simulated by the TD-DFT method [M06/6-31G* (C, H, N), LANL2DZ (Pt)], nstates $=40$, peak half-width at half height $=0.2 \mathrm{eV}$. Vertical blue lines represent $R_{\text {vel }}$ and oscillator strength. 

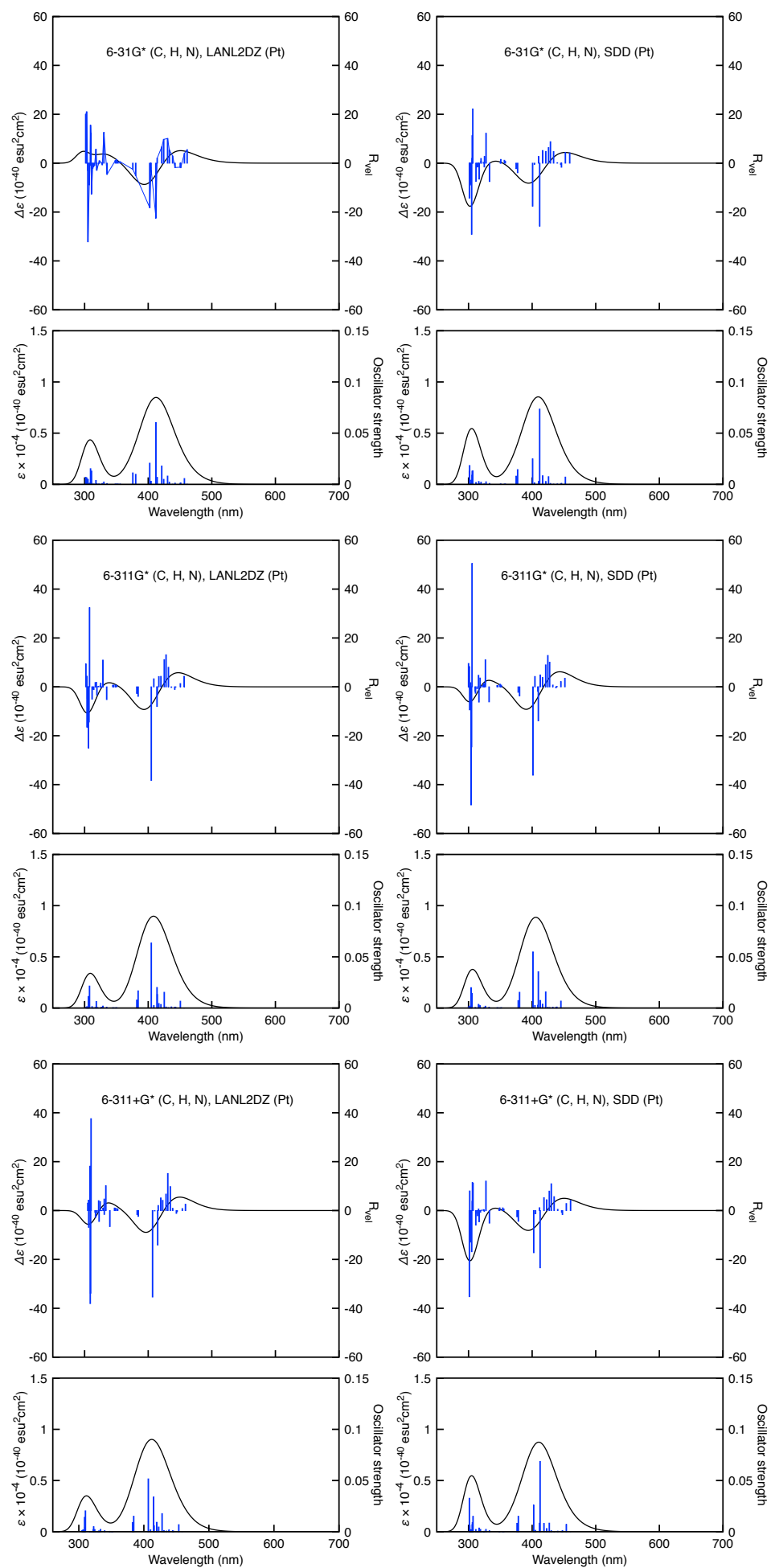

Figure S42. Solid black curves: $\mathrm{CD}$ and UV-vis absorption spectra of $\operatorname{Pt}(\mathrm{bpy})(\mathrm{C} \equiv \mathrm{C}-\mathrm{H})_{2}$... $\operatorname{Pt}($ bpy $)(\mathrm{C} \equiv \mathrm{C}-\mathrm{H})_{2}\left(\Phi=195^{\circ}\right)$ simulated by the TD-DFT method using M06 as a functional and various basis sets described at the top of each chart, nstates $=40$, peak half-width at half height $=$ $0.2 \mathrm{eV}$. Vertical blue lines represent $R_{\text {vel }}$ and oscillator strength. 

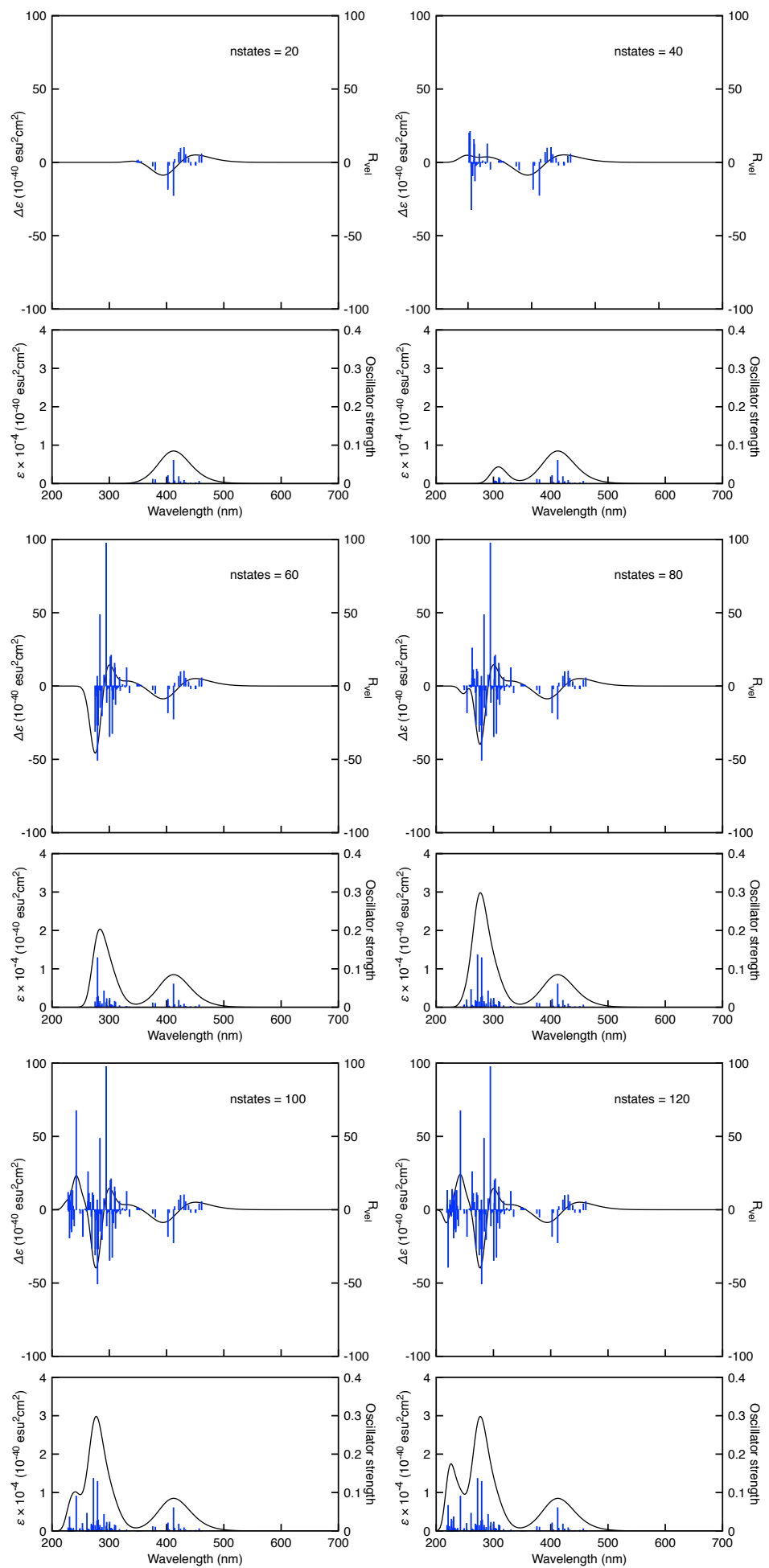

Figure S43. CD and UV-vis absorption spectra of $\mathrm{Pt}(\mathrm{bpy})(\mathrm{C} \equiv \mathrm{C}-\mathrm{H})_{2} \bullet \operatorname{Pt}(\mathrm{bpy})(\mathrm{C} \equiv \mathrm{C}-\mathrm{H})_{2}(\Phi=$ $195^{\circ}$ ) simulated by the TD-DFT method using M06 as a functional and 6-31G* $(\mathrm{C}, \mathrm{H}, \mathrm{N})$, LANL2DZ $(\mathrm{Pt})$ with various nstates described at the top of each chart, peak half-width at half height $=0.2 \mathrm{eV}$. Vertical blue lines represent $R_{\mathrm{vel}}$ and oscillator strength. 


\section{Conformers of Dimer ••• Dimer Association Models}

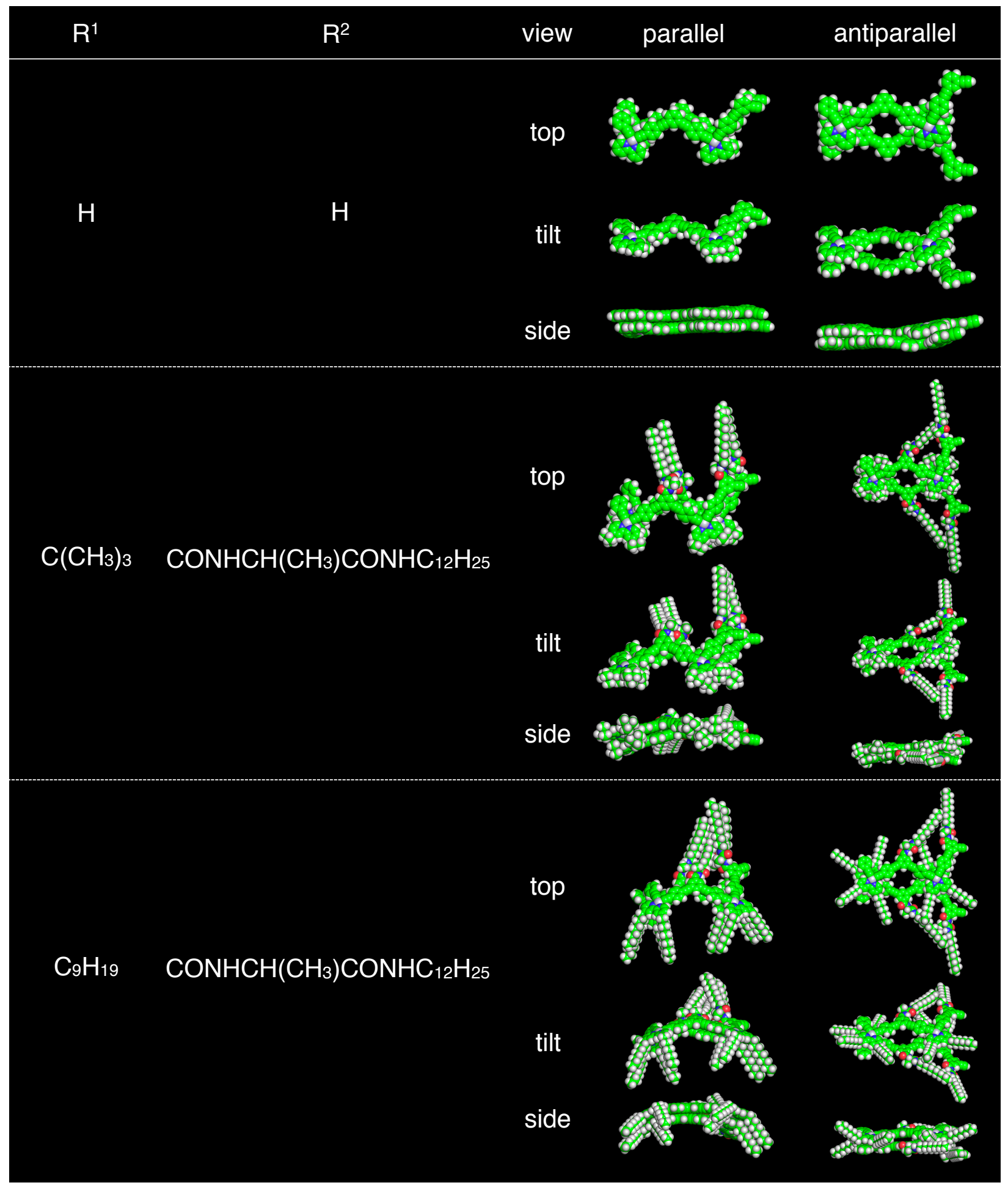

Figure S44. Top, tilt and side views of parallel and antiparallel dimer $\cdots$ dimer association models. $\mathrm{R}^{1}$ and $\mathrm{R}^{2}$ correspond to the substituents at the bipyridine illustrated in Figure 13. The geometries were optimized by the DFT method [M06/6-31G* (C, H, N), LANL2DZ (Pt)]. 


\section{Table S2. Dihedral Angles of Parallel and Antiparallel Dimer ••• Dimer Association Models ${ }^{a}$}

\begin{tabular}{|c|c|c|c|c|c|}
\hline \multirow{2}{*}{ model } & \multirow{2}{*}{$\mathrm{R}^{1}$} & \multirow{2}{*}{$\mathrm{R}^{2}$} & \multicolumn{2}{|c|}{$\Phi^{b}($ degree $)$} & \multirow{2}{*}{$\begin{array}{c}|\Phi| \text { average }^{d} \\
(\text { degree })\end{array}$} \\
\hline & & & unit $1^{c}$ & unit $2^{c}$ & \\
\hline simplified parallel dimer & $\mathrm{H}$ & $\mathrm{H}$ & -3 & +5 & 4 \\
\hline simplified antiparallel dimer & $\mathrm{H}$ & $\mathrm{H}$ & -216 & +216 & 216 \\
\hline poly(1a-2) parallel dimer & $\mathrm{C}\left(\mathrm{CH}_{3}\right)_{3}$ & $\mathrm{CONHCH}\left(\mathrm{CH}_{3}\right) \mathrm{CONHC}_{12} \mathrm{H}_{25}$ & +21 & +6 & 14 \\
\hline poly(1a-2) antiparallel dimer & $\mathrm{C}\left(\mathrm{CH}_{3}\right)_{3}$ & $\mathrm{CONHCH}\left(\mathrm{CH}_{3}\right) \mathrm{CONHC}_{12} \mathrm{H}_{25}$ & -217 & +214 & 216 \\
\hline poly(1b-2) parallel dimer & $\mathrm{C}_{9} \mathrm{H}_{19}$ & $\mathrm{CONHCH}\left(\mathrm{CH}_{3}\right) \mathrm{CONHC}_{12} \mathrm{H}_{25}$ & -13 & +2 & 8 \\
\hline poly(1b-2) antiparallel dimer & $\mathrm{C}_{9} \mathrm{H}_{19}$ & $\mathrm{CONHCH}\left(\mathrm{CH}_{3}\right) \mathrm{CONHC}_{12} \mathrm{H}_{25}$ & -214 & +213 & 214 \\
\hline
\end{tabular}


Examination of Stabilization upon Association by Hydrogen Bonding. The DFT calculations of model compounds of poly(1a-2) and poly(1b-2) were carried out using the M06 functional and 6-31G* $(\mathrm{C}, \mathrm{H}, \mathrm{N}, \mathrm{O})$ LANL2DZ (Pt) basis set. Aggregated tetramers of model compounds (Figure S45) of poly(1a-2) and poly(1)-2) were constructed, wherein the positions of the model molecules were adjusted for the amide groups to form intermolecular hydrogen bonding, and the molecules were regularly twisted at the center of the benzene ring with the amide group in the initial geometries. Figure S46 plots the relationships between the relative stabilization energy per one molecule, and degree of association (1-4, monomer-tetramer) of poly(1a-2) and poly(1)-2) models. The relative stabilization energy became negative as raising the degree of association in the both model compounds. The tetramer of poly $(\mathbf{1} \mathbf{b}-\mathbf{2})$ model was $25.7 \mathrm{~kJ} / \mathrm{mol}$ relatively more stable than that of poly(1a-2) model. Poly(1)-2) with nonyl groups seems to aggregate more largely compared to poly(1a-2) with bulky tert-butyl groups. These data reasonably explain the solubility difference between the two polymers as mentioned above, and the difference of stabilization energy upon aggregation.

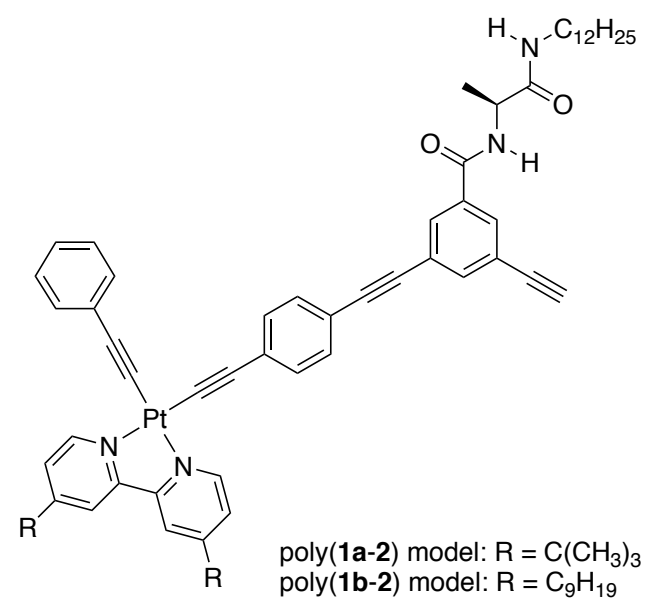

Figure S45. Structures of model compounds of poly(1a-2) and poly(1)-2). 

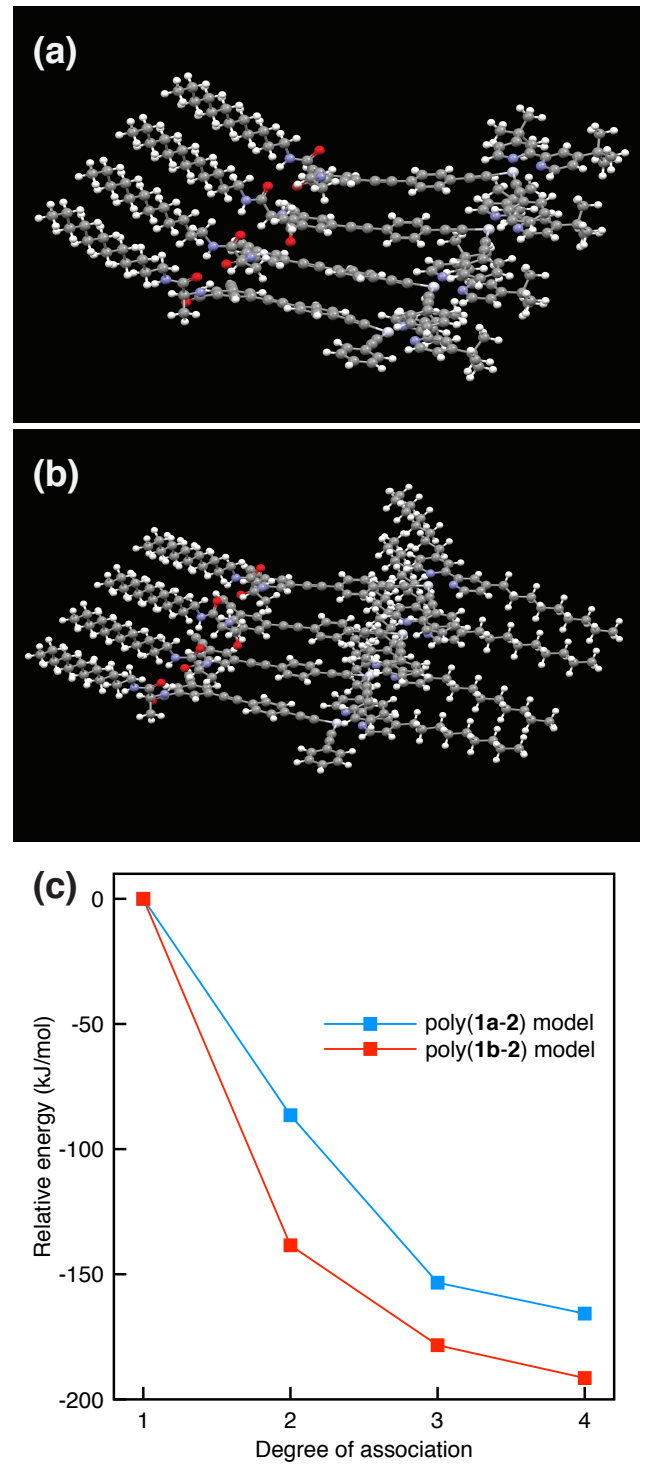

Figure S46. Possible conformations of aggregated tetramer models of (a) poly(1a-2) and (b) poly(1b-2). The geometries were optimized by the DFT method [M06/6-31G* (C, H, N, O)LANL2DZ (Pt)]. (c) Relationships between the degree of association and relative energy of poly(1a-2) and poly(1b-2) models calculated by the DFT method [M06/6-31G* $(\mathrm{C}, \mathrm{H}, \mathrm{N}, \mathrm{O})$ LANL2DZ (Pt)]. 


\section{REFERENCES}

S1) Dolomanov, O.V.; Bourhis, L. J.; Gildea, R. J.; Howard, J. A. K.; Puschmann, H. OLEX2: A Complete Structure Solution, Refinement and Analysis Program. J. Appl. Cryst. 2009, 42, 339-341.

S2) Otaki, Y.; Marumoto, M.; Miyagi, Y.; Hirao, T.; Haino, T.; Sanda, F. Synthesis and Properties of Novel Optically Active Platinum-containing Poly(phenyleneethynylene)s. Chem. Lett. 2016, 45, 937-939.

S3) Suzuki, S.; Matsuura, K.; Nakazono, K.; Takata, T.; Effect of a Side Chain Rotaxane Structure on the Helix-folding of Poly(m-phenylene diethynylene). Polym. J. 2014, 46, 355-365.

S4) Aujard. I.; Baltaze, J.-P.; Baudin, J.-B.; Congé, E.; Ferrange, F.; Jullien, L.; Perez, É.; Prévost, V.; Qian, L. M.; Ruel, O. Tetrahedral Onsager Crosses for Solubility Improvement and Crystallization Bypass. J. Am. Chem. Soc. 2001, 123, 8177-8188.

S5) Goeb, S.; Ziessel, R.; Org. Lett. Convenient Synthesis of Diisoindolodithienylpyrromethene-Dialkynyl Borane Dyes. Org. Lett. 2007, 9, 737-740.

S6) Frisch, M. J.; Trucks, G. W.; Schlegel, H. B.; Scuseria, G. E.; Robb, M. A.; Cheeseman, J. R.; Scalmani, G.; Barone, V.; Mennucci, B.; Petersson, G. A.; Nakatsuji, H.; Caricato, M.; Li, X.; Hratchian, H. P.; Izmaylov, A. F.; Bloino, J.; Zheng, G.; Sonnenberg, J. L.; Hada, M.; Ehara, M.; Toyota, K.; Fukuda, R.; Hasegawa, J.; Ishida, M.; Nakajima, T.; Honda, Y.; Kaito, O.; Nakai, H.; Vreven, T.; Montgomery Jr, J. A.; Peralta, J. E.; Ogliaro, F.; Bearpark, M.; Heyd, J. J.; Brothers, E.; Kudin, K. N.; Sraroverov, V. N.; Keith, T.; Kobayashi, R.; Normand, J.; Raghavachari, K.; Rendell, A.; Burant, J. C.; Iyengar, S. S.; Tomasi, J.; Cossi, M.; Rega, N.; Milam, J. M.; Klene, M.; Knox, J. E.; Cross, J. B.; Bakken, V.; Adamo, C.; Jaramillo, J.; Gomperts, R.; Stramann, R. E.; Yazyev, O.; Austin, A. J.; Cammi, R.; Pomelli, C; Ochterski, J. W.; Martin, R. L.; Morokuma, K.; Zakrzewski, V. G.; Voth, G. A.; Salvador, P.; Dannenberg, J. J.; Dapprich, S.; Daniels, A. D.; Frakas, O.; Foresman, J. B.; Ortiz, J. V.; Ciosloski, J; Fox, D. J. Gaussian 16, Revision, B.01, Gaussian, Inc., Wallingford CT (2016).

S7) R. G. Parr and W. Yang. Density-Functional Theory of Atoms and Molecules. Oxford University Press, Oxford (1989). 